\title{
Chloride Channel Blockers Suppress Formation of Engulfment Pseudopodia in Microglial Cells
}

\author{
Barbara Harla Judith Schmölzera,b Martin Jakab ${ }^{\mathrm{b}}$ Markus Ritter ${ }^{\mathrm{b}, \mathrm{c}}$ Hubert H. Kerschbaum ${ }^{\mathrm{a}}$

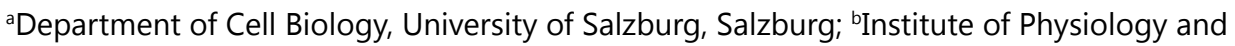 \\ Pathophysiology, Paracelsus Medical University, Salzburg; 'Gastein Research Institute, Paracelsus \\ Medical University, Salzburg
}

\section{Key Words}

$\mathrm{Cl}^{-}$-conductance - Hyperosmotic solution - Hypoosmotic solution - Microglial BV-2 cells • Primary microglial cells • Phagocytosis • Cell volume

\begin{abstract}
Background/Aims: Phagocytosis depends on the formation of engulfment pseudopodia surrounding the target. We tested in microglia, monocyte-derived cells in the brain, whether a swelling-activated $\mathrm{Cl}^{-}$-current $\left(\mathrm{I}_{\mathrm{Cl}}\right.$, swell $)$, required for global cell volume $(\mathrm{CV})$ regulation, also contributes to local expansion and retraction of engulfment pseudopodia. Methods: We used scanning electron microscopy (SEM) and confocal laser scanning microscopy (CLSM) to visualize and quantify the uptake of polystyrene microbeads (MBs) by microglial cells. Flow cytometry was used for cell volume measurments and $\mathrm{I}_{\mathrm{Cl}}$, swell was measured by whole-cell patch clamp. Results: We found that exposure of microglial BV-2 cells to MBs in $\mathrm{Cl}^{-}$-free extracellular solution attenuated $\mathrm{MB}$ uptake and that the $\mathrm{Cl}^{-}$-channel blockers DIOA, flufenamic acid, NPPB and DCPIB suppressed the uptake of MBs in BV-2 cells and in primary microglial cells. Microglial cells exposed to MBs in the presence of $\mathrm{Cl}^{-}$channel blockers failed to extend engulfment pseudopodia. We observed that cells containing at least three MBs revealed an about twofold increase in current density of $\mathrm{I}_{\mathrm{Cl} \text {, swell }}$ compared to cells without $\mathrm{MB}$. Osmotic challenges to stimulate global CV regulation before exposure to MBs modulated phagocytosis. Pre-conditioning of cells in hypo- or hypertonic medium for 12-16 hours caused a decrease in MB uptake. Conclusion: These findings indicate that $\mathrm{I}_{\mathrm{Cl} \text {, swell }}$ contributes to formation of engulfment pseudopodia and participates in engulfment and particle uptake in microglial cells.
\end{abstract}


Harl/Schmölzer/Jakab/Ritter/Kerschbaum: Chloride Channel Blockers Suppress Phagocytosis

\section{Introduction}

Anion-conductance activation is one of the earliest events in the innate immune responses. Recognition of opsonised Candida albicans by human polymorphonuclear neutrophil leucocytes (PMNs) triggers the efflux of $\mathrm{Cl}^{-}$in these cells [1]. Accordingly, inhibition of $\mathrm{Cl}^{-}$-channel activity in human PMNs decreases the uptake of opsonized zymosan [2]. Similarly, blockade of $\mathrm{Cl}^{-}$-conductance in rodent microglia, monocyte-derived cells in the nervous system, suppresses phagocytosis of $E$. coli [3] or engulfment of microspheres (microbeads, MBs) [4]. In contrast to uptake of particles, blockade of chloride intracellular ion channel 1 (CLIC1) increases amyloid-beta (A $\beta$ ) uptake in microglia and macrophages [5]. In addition to its involvement in the recognition and uptake of particles, $\mathrm{Cl}-$-channels have been associated with pathogen killing in phagolysosomes. Cystic fibrosis transmembrane conductance regulator (CFTR), acting as cAMP-regulated $\mathrm{Cl}^{-}$-channel, and the $\mathrm{Cl}^{-}$-channel $\mathrm{ClC}$ 3 are localized in the membrane of phagolysosomes in phagocytes [2, 6, 7]. Phagolysosomes from patients suffering from cystic fibrosis (CF) or from CFTR deficient mice show impaired acidification, defect chlorination of bacterial proteins and, consequently, inefficient killing of bacteria [6,7]. Thus, anion-channels in the plasma membrane as well as in intracellular organelles (phagolysosomes) are crucially involved in phagocytosis and killing of pathogens.

Although several studies demonstrate the importance of a $\mathrm{Cl}^{-}$-conductance in the early phase of phagocytosis, the mechanistic consequences of a change in $\mathrm{Cl}$-conductance are not known. In the present study, we propose that activation of $\mathrm{Cl}^{-}$-conductance is a prerequisite for the formation of engulfment pseudopodia. Following recognition of a particle, engulfment pseudopodia extend from the cell surface, tightly embrace particles and expand until entire engulfment is accomplished. The formation of engulfment pseudopodia may be envisioned as local subcellular volume changes. Similar to global cell volume (CV) regulation [8-10], influx or efflux of osmolytes along osmotic gradients, which is restricted to specific subcellular regions, provokes local cell swelling or shrinkage, respectively. In such a scenario influx of water should promote extension of engulfment pseudopodia, whereas efflux of water would accomplish the retraction phase. Applying the concept of global CV regulation to the formation of engulfment pseudopodia predicts three consequences: (i) If local volume regulation resembles global $\mathrm{CV}$ regulation, ion channels and transporters involved in regulatory volume increase (RVI) and decrease (RVD) are involved in formation of engulfment pseudopodia. A key ion in global CV regulation is $\mathrm{Cl}^{-}$[11-14]. Therefore, blockade of $\mathrm{Cl}^{-}$-conductances is expected to prevent local volume changes and suppress particle uptake. (ii) CV regulation is closely associated with osmotic challenges. Particle uptake and digestion lead to an increase in osmotic pressure, which needs to be counterbalanced by regulation of osmolytes. Exemplified by hepatocytes, glucagon not only promotes catabolism of glycogen to glucose, but also activates CV regulatory $\mathrm{K}^{+}$fluxes and volume-activated $\mathrm{Cl}^{-}$channels [15-17]. Similarly, in phagocytes the uptake of particles could promote an increase in $\mathrm{Cl}^{-}$-conductance to prevent deleterious osmotic stress. Accordingly, an increase in the amplitude of the swelling-activated $\mathrm{Cl}^{-}$-current $\left(\mathrm{I}_{\mathrm{Cl} \text { swell }}\right)$ is expected following particle uptake. (iii) If there is a mutual interaction between osmoregulation and phagocytosis, exposure of cells to osmotic challenges prior to application of particles will modulate the phagocytotic capacity.

We validated our predictions by exposing primary microglial cells as well as the microglial cell line BV-2, to MBs. We used polystyrene MBs to avoid interferences of signalling cascades induced by the MB uptake with those elicited by biological material, like pathogen associated molecular patterns (PAMP). To unequivocally distinguish between attached and internalized MBs, we used in most experiments scanning electron microscopy (SEM). Particle uptake was quantified at the single cell level in the absence of extracellular $\mathrm{Cl}^{-}$as well as in the presence or absence of $\mathrm{Cl}^{-}$-channel blockers. The mutual modulation of phagocytosis and osmoregulation was evaluated by analysing long term consequences of phagocytosis on $\mathrm{I}_{\mathrm{Cl} \text {, swell }}$ densities as well as by quantifying the consequences of long term osmotic challenges on MB uptake. 


\section{Materials and Methods}

\section{Cell culture}

Primary microglial cells were isolated from forebrains of one- to three day old wild-type C57 black 6J mice [18]. Mice were killed by decapitation. After dissociation of brain tissue with trypsin for $30 \mathrm{~min}$ at $37^{\circ} \mathrm{C}$ and mechanical dissociation by centrifugation, microglia were co-cultivated with astrocytes in poly-D-lysine (PDL)-coated $75 \mathrm{~cm}^{2}$ tissue culture flasks in Dulbecco's modified Eagle's medium (DMEM) supplemented with $10 \%$ fetal calf serum (FCS; Gibco/BRL Life Technologies, MD, USA) and 1\% penicillin /streptomycin (Gibco). 6 to 9 animals were used per cell culture. After $10-14$ days in culture at $37^{\circ} \mathrm{C}$ and $5 \% \mathrm{CO}_{2}$, primary microglial cells were harvested by vigorous shaking from an astrocyte monolayer for $3 \mathrm{~h}$. The supernatant containing $>97 \%$ microglia was used for experiments. Adult wild-type C57 black 6J mice were ordered from and bred in the local animal housing at the University of Salzburg. Animal handling was performed according to Austrian law and approved by local authorities.

The murine microglial cell line BV-2 was cultured in $25 \mathrm{~cm}^{2}$ tissue culture flasks in DMEM containing $2200 \mathrm{mg} / \mathrm{L}$ glucose supplemented with $10 \% \mathrm{FCS}$ at $37^{\circ} \mathrm{C}$ in a humidified atmosphere at $5 \% \mathrm{CO}_{2}$. Twice a week cells were split and supplied with new medium.

For experiments, BV-2 cells and primary microglial cells were treated with trypsin (2.5\%, $1 \mathrm{ml}$ for $3 \mathrm{~min}$ ) to detach from culture flasks. Following detachment, cell suspension was transferred into a centrifugation tube containing $8 \mathrm{ml} \mathrm{DMEM} \mathrm{+10 \%} \mathrm{FCS} \mathrm{and} \mathrm{centrifuged} \mathrm{at} 200 \times \mathrm{g}$ for $5 \mathrm{~min}$. Cells were re-suspended in 1 $\mathrm{ml} \mathrm{DMEM}+10 \%$ FCS, seeded into Petri dishes $(\varnothing 3.5 \mathrm{~cm})$ on PDL-coated $(0.01 \%$ for BV-2 cells; $0.1 \%$ for primary microglia) glass coverslips ( $\varnothing 12 \mathrm{~mm}$ ) and incubated for up to $18 \mathrm{~h}$ to allow for adhesion. Following two washes in extracellular solution, cells were treated with different reagents in extracellular solution.

\section{Reagents and solutions}

The $\mathrm{Cl}^{-}$-channel blocker 4-[(Butyl-6,7-dichloro-2-cyclopentyl-2,3-dihydro-1-oxo-1H-inden-5-yl)oxy] butanoic acid (DCPIB), the $\mathrm{Cl}^{-}$-channel- and $\mathrm{K}^{+}-\mathrm{Cl}^{-}$-cotransport inhibitor $\mathrm{R}(+)[(2-n-$ butyl-6,7-dichloro-2cyclopentyl-2,3-dihydro-1-oxo-1H-inden-5-yl)oxy] (DIOA), and the $\mathrm{Cl}^{-}$-channel blockers flufenamic acid (FFA) and 5-nitro-2-(3-phenylpropylamino)benzoic acid (NPPB) were from Tocris (Ellisville, MO, USA).

Extracellular solution ( 300 mosmol/L) contained (in mM): $\mathrm{NaCl}, 130 ; \mathrm{KCl}, 5 ; \mathrm{CaCl}_{2}, 2 ; \mathrm{MgCl}_{2}, 1 ; \mathrm{HEPES}$ (4-(2-hydroxyethyl)-1-piperazineethanesulfonic acid), 10; D-glucose, 8; titrated to pH 7.4 with $\mathrm{NaOH}$. $\mathrm{Cl}^{-}-$ free extracellular solution ( $300 \mathrm{mosmol} / \mathrm{L})$ contained (in mM): Na-D-gluconate, 130; K-D-gluconate, 5; CaD-gluconate monohydrate, 2; $\mathrm{MgSO}_{4}$, 1; HEPES, 10; D-glucose, 8; titrated to $\mathrm{pH} 7.4$ with $\mathrm{NaOH}$. The measured concentration of ionized calcium in this solution was $0.31 \mathrm{mM}$. Phosphate buffered saline (PBS) contained (in mM): $\mathrm{NaCl}, 150 ; \mathrm{KH}_{2} \mathrm{PO}_{4}, 2 ; \mathrm{Na}_{2} \mathrm{HPO}_{4}, 6.4$; titrated to $\mathrm{pH} 7.4$ with $\mathrm{NaOH}$. In a $5 \% \mathrm{CO}_{2}$ atmosphere of the incubator, the $\mathrm{pH}$ in the HEPES-buffered extracellular solution did not change within $15 \mathrm{~min}$, but decreased from 7.4 to 7.2 within $1 \mathrm{~h}$. Long-term incubation (12 h) of cells in anisoosmotic solutions was performed in DMEM containing 10\% FCS. Short-term incubation (15 min, $1 \mathrm{~h}$ ) of cells in anisoosmotic solutions was performed in extracellular solutions. Hypertonic solution (400 mosmol/L) was adjusted by addition of sucrose, and hypotonic solution (200 mosmol/L) was adjusted by dilution with Aqua bidestillata. After 12 $\mathrm{h}$ exposure in $\mathrm{CO}_{2}$ atmosphere, the $\mathrm{pH}$ of the diluted buffer was 7.3. Osmolarity was checked by freezing point depression (OM802; Vogel, Giessen, Germany). All chemicals were from Sigma-Aldrich (St. Luis, Missouri, USA). Red fluorescent sulfate polystyrene microspheres ( $2 \%$ solids, $\emptyset 4 \mu \mathrm{m})$ were purchased from Invitrogen (Life Technologies, Vienna, Austria).

\section{Flow cytometry - Cell volume (CV) regulation}

$\mathrm{CV}$ regulation in BV-2 cells was evaluated using flow cytometry by determination of the forward scatter integral area (FSC-A). Cells were seeded in uncoated Petri dishes ( $\varnothing 35 \mathrm{~mm}$ ) at a density of $1 \times 10^{5}$ cells in DMEM with $10 \% \mathrm{FCS}$ overnight at $37^{\circ} \mathrm{C}$ and $5 \% \mathrm{CO}_{2}$. After trypsination and centrifugation at $200 \times \mathrm{g}$ for $5 \mathrm{~min}$, cells were re-suspended in $1 \mathrm{ml}$ extracellular solution. After $5 \mathrm{~min}$ cells were exposed to hypotonic solution (200 mosmol/L) in the presence or absence of $5 \mu \mathrm{M}$ DCPIB, or $200 \mu \mathrm{M}$ FFA. At one minute intervals CV was measured using a FACSCanto ${ }^{\mathrm{TM}}$ II Flow Cytometry System (BD Bioscience, San Jose, CA, USA) by measuring FSC-A by counting 10,000 cells per time-point. Data were analysed using the Win MDI 2.9 software. 
Harl/Schmölzer/Jakab/Ritter/Kerschbaum: Chloride Channel Blockers Suppress

Phagocytosis

\section{Scanning electron microscopy}

For scanning electron microscopy (SEM), microglial cells were seeded on PDL coated glass coverslips (Ø $12 \mathrm{~mm}$ ) at a density of $6 \times 10^{4}$ cells in DMEM with $10 \% \mathrm{FCS}$ and allowed to adhere overnight at $37^{\circ} \mathrm{C}$ and $5 \% \mathrm{CO}_{2}$.

For anion channel blocker experiments cells were washed twice and incubated in extracellular solution. Phagocytosis of microglial cells was assessed after incubation with MBs $\left(3.41 \times 10^{6} \mathrm{MBs} / 2 \mathrm{ml}\right.$ solution $)$ in the absence and presence of the channel blockers DCPIB, DIOA, FFA and NPPB for 15 min and/or $1 \mathrm{~h}$ at 37 ${ }^{\circ} \mathrm{C}$ and $5 \% \mathrm{CO}_{2}$. Added MBs were stationary at the site of sedimentation and did not float or move within the culture dish. After incubation, cells were washed with extracellular solution and PBS and fixed in $2.5 \%$ glutaraldehyde at room temperature for $1 \mathrm{~h}$ and washed in PBS overnight. Cells were dehydrated in ethanol series (50-70-80-90-96-100-100-100\%) for $5 \mathrm{~min}$ each and dried in a critical point drying apparatus (Critical Point Dryer LPD030, Baltec, Liechtenstein). After placing the coverslips on a SEM-stub, microglial cells were covered with gold (Sputter Coater/ Agar Scientific, England) and observed using a Cambridge Stereoscan 250 scanning electron microscope. Electron micrographs were digitized and analysed via Orion software (ORION, E.L.I. sprl, Belgium).

For experiments in $\mathrm{Cl}^{-}$-free extracellular solution, cells were washed twice and incubated with MBs $\left(3.41 \times 10^{6} \mathrm{MBs} / 2 \mathrm{ml}\right.$ solution) for $15 \mathrm{~min}$ and $1 \mathrm{~h}$, respectively, in $\mathrm{Cl}^{-}$-free solution at $37^{\circ} \mathrm{C}$ and $5 \% \mathrm{CO}_{2}$. After incubation times further processing followed as described above.

For long-term experiments with hypertonic or hypotonic solutions, cells were washed two times with hypertonic (400 msomol/L) or hypotonic (200 mosmol/L) solution and incubated in it for $12 \mathrm{~h}$ at $37^{\circ} \mathrm{C}$ and $5 \% \mathrm{CO}_{2}$. After exposure to anisotonic conditions, cells were exposed (i) for $15 \mathrm{~min}$ to $\mathrm{MBs}\left(3.41 \times 10^{6} \mathrm{MBs}\right.$ / $2 \mathrm{ml}$ solution) in isotonic saline, (ii) for $15 \mathrm{~min}$ in isotonic saline followed by further $15 \mathrm{~min}$ in isotonic conditions in the presence of MBs, (iii) for $1 \mathrm{~h}$ in isotonic saline containing MBs, and (iv) for $15 \mathrm{~min}$ in isotonic saline followed by $1 \mathrm{~h}$ in isotonic conditions in the presence of MBs. After different incubation times, cells were treated as described for anion channel blocker experiments.

\section{Confocal laser scanning microscopy (CLSM)}

For fluorescence microscopy BV-2 cells were plated on $0.01 \%$ PDL coated glass coverslips ( $\varnothing 20 \mathrm{~mm}$ ) at a density of $6 \times 10^{4}$ cells in DMEM and $10 \%$ FCS for $12-18 \mathrm{~h}$. After two washing steps with extracellular solution, cells were incubated in hypertonic solutions (400, 450, $500 \mathrm{mosmol} / \mathrm{L})$ with MBs $\left(3.41 \times 10^{6} \mathrm{MBs} /\right.$ $2 \mathrm{ml}$ solution) for $15 \mathrm{~min}$ and $1 \mathrm{~h}$, respectively, at $37^{\circ} \mathrm{C}$ and $5 \% \mathrm{CO}_{2}$. After the incubation, cells were washed with extracellular solution and PBS and fixed with methanol and glacial acetic acid (3:1) for 20 min at room temperature. Nuclei were stained with DAPI (Sigma-Aldrich, USA) for $30 \mathrm{~min}$. Thereafter cells were washed with PBS and distilled water and coverslips were embedded in glycergel (DakoCytomation, USA) and stored at $4{ }^{\circ} \mathrm{C}$ until use.

Phagocytosis of MBs was visualized with a confocal laser scanning microscope (CLSM 510 Meta, Zeiss, Germany) using an UV laser $\left(\lambda_{\text {ex }}=364 \mathrm{~nm}\right)$ to detect DAPI stained blue nuclei and a helium-neon laser $\left(\lambda_{\text {ex }}=\right.$ $543 \mathrm{~nm}$ ) to visualize red MBs. Images were digitized and processing was performed with a Zeiss LSM Image Examiner.

\section{Determination of successful particle binding, engulfment and internalisation}

For the assessment of MB binding the number of particles attached on microglia cells were counted numerically. Successful MB engulfment and internalization was detected by microglia whole particle engulfment using SEM, which is clearly visible due to the spherical shape of the MBs. Using CLSM, successful particle internalization was observed when the MBs were in the same optical plane as the nuclei.

\section{Electrophysiology}

BV-2 cells were plated on PDL (0.01\%)-coated glass coverslips ( $\varnothing 12 \mathrm{~mm}$ ) and grown for at least 48 $\mathrm{h}$ in DMEM. BV-2 cells were pre-incubated with polystyrene MBs $(\varnothing 4 \mu \mathrm{m})$ for at least $45 \min$ up to $5 \mathrm{~h}$. Electrophysiological recordings were performed on cells with three or more incorporated MBs. For long-term osmotic challenge (12-16 h), BV-2 cells were pre-incubated with hypotonic (200 mosmol/L) or hypertonic (400 mosmol/L) DMEM, respectively. Cl-currents were monitored in the standard whole-cell recording mode $[19,20]$ with an EPC-10 patch clamp amplifier (HEKA Elektonik, Lambrecht, Germany) connected to a computer running Patchmaster / Fitmaster 2.65 data acquisition / analysis software. After establishing 
Harl/Schmölzer/Jakab/Ritter/Kerschbaum: Chloride Channel Blockers Suppress

Phagocytosis

the whole cell configuration, cells were superfused with isotonic extracellular solution containing (in mM): $\mathrm{NaCl}, 160 ; \mathrm{CaCl}_{2}, 2 ; \mathrm{MgCl}_{2}, 1$; HEPES-FA, 5; titrated to $\mathrm{pH} 7.4$ with $\mathrm{NaOH}$ and an osmolarity of 308-310 mosmol/L, using a gravity-flow permanent perfusion system.

$\mathrm{I}_{\mathrm{Cl} \text {, swell }}$ was elicited by osmotic stress in two different ways: (i) by a $85 \%$ hypoosmotic external solution, which was prepared by diluting the isotonic extracellular solution with distilled water in combination with an isotonic intracellular solution containing (in mM): $\mathrm{CsCl}, 160 ; \mathrm{MgCl}_{2}$, 2; HEPES-FA, 10; EGTA, 11; Mg-ATP, 4; titrated to $\mathrm{pH} 7.2$ with $\mathrm{CsOH}$ and an osmolarity of 314 mosmol/L. (ii) By a hypertonic intracellular solution containing (in mM): CsCl, 160; $\mathrm{MgCl}_{2}$, 5; HEPES-FA, 10; EGTA, 11; D-Mannitol, 30; Mg-ATP, 2; titrated to pH 7.2 with $\mathrm{CsOH}$ and an osmolarity of $374 \mathrm{mosmol} / \mathrm{L}$ in combination with the isotonic extracellular solution. Both salines are symmetric $\mathrm{Cl}^{-}$solutions. Osmolarities were measured with a vapor pressure osmometer (Wescor, Logan, Utah, USA). Resistances of electrodes filled with the hypertonic intracellular pipette solutions ranged from 2 to $5 \mathrm{M} \Omega$. Patch pipettes were pulled from WPI $1.5 \mathrm{~mm}$ diameter glass capillaries (WPI, Glass 1BBL W/ Fl 1.5mm 3IN) in three stages and fire polished using a Narishige MF-9 microforge (NarishigeCo., Ltd, Tokyo, Japan). Immediately after forming a stable whole cell configuration, membrane (C-slow) and pipette (C-fast) capacitances were compensated using an electronic feedback via the patch clamp amplifier. Liquid junction potential between pipette and bath solution $(<20 \mathrm{mV})$ was not corrected. In all experiments the holding potential was kept at $0 \mathrm{mV}$ to block voltage dependent currents. The $\mathrm{Cl}$-current was monitored either during a 500-ms voltage ramp from $-100 \mathrm{mV}$ to $+100 \mathrm{mV}$ elicited at a frequency of $10 \mathrm{sec}$, or during 500-ms voltage steps from $-100 \mathrm{mV}$ to $+100 \mathrm{mV}$ with an increment of $20 \mathrm{mV}$. All electrophysiological measurements were performed at room temperature. Further data analysis was performed using the Igor Pro 3.1 (Wave Metrics, Oregon, USA) software package and GraphPad Prism 4 (GraphPad Software, Inc.).

\section{Statistical analysis}

All data are presented as mean \pm standard error of the mean (s.e.m.). Statistical analysis was performed using the SPSS 18.0 software. Each experiment was conducted at least for three times (in each experiment 100-200 cells were randomly counted), Student's double-sided t-test for independent samples and analysis of variance (ANOVA) followed by the Dunnett's post hoc test was applied to calculate levels of significance, $\mathrm{P}<0.05$ and $\mathrm{P}<0.01$. All electrophysiology data are presented as mean \pm s.e.m. Statistical analyses ( $\mathrm{t}$-tests) were performed using GraphPad Prism 4. Sample sizes are depicted in the figures.

\section{Results}

Cl-channel blockers suppress $I_{C l, \text { swell, }}$ uptake of microbeads, and formation of engulfment pseudopodia

Cell swelling induced by perfusion with a hypotonic extracellular solution or by dialyzing cells with a hypertonic intracellular solution activated an outwardly rectifying current in BV-2 cells over time $\left(\mathrm{I}_{\mathrm{cl} \text {, swell }} ;\right.$ Fig.1A, B). This current was present in asymmetric [21] as well as in symmetric distribution of $\mathrm{Cl}^{-}$in the extra- and intracellular solutions, which is reflected in a reversal potential close to $0 \mathrm{mV}$. NPPB $(100 \mu \mathrm{M})$, DIOA $(100 \mu \mathrm{M})$, FFA $(200 \mu \mathrm{M})$, and DCPIB $(5 \mu \mathrm{M})$ completely blocked the inward as well as the outward current. NPPB blocked both the inward and outward current at -100 and $+100 \mathrm{mV}$, respectively, with an $I C_{50}$ of $\sim 4$ $\mu \mathrm{M}(\mathrm{n}=3)$ (Fig. 1C).

Formation of contact-induced engulfment pseudopodia and the following engulfment took place all over the cell body and was not restricted to the lamellipodium (Fig. 2A, B).

To test for $\mathrm{Cl}^{-}$-dependency of phagocytosis, BV-2 cells were incubated in nominally $\mathrm{Cl}^{-}$free extracellular solution and the relative number of engulfed MBs was counted. As shown in Figure 3, MB uptake was unaffected after $15 \mathrm{~min}$, but significantly attenuated by $\sim 40 \%$ after $1 \mathrm{~h}$.

Under control conditions the overall number of BV-2 cells containing MBs was dependent on the incubation time. After $15 \mathrm{~min}$ and $1 \mathrm{~h}$ the relative number of MB containing cells was $46.8 \pm 2.5 \%$ and $81.7 \pm 5.2 \%$, respectively (Fig. $4 \mathrm{~A})$. In the presence of DCPIB $(20 \mu \mathrm{M})$, DIOA $(100 \mu \mathrm{M})$, FFA $(200 \mu \mathrm{M})$ and NPPB $(200 \mu \mathrm{M})$ the phagocytotic capacity was markedly depressed or inhibited almost completely. To analyse this behaviour on the single cell level 

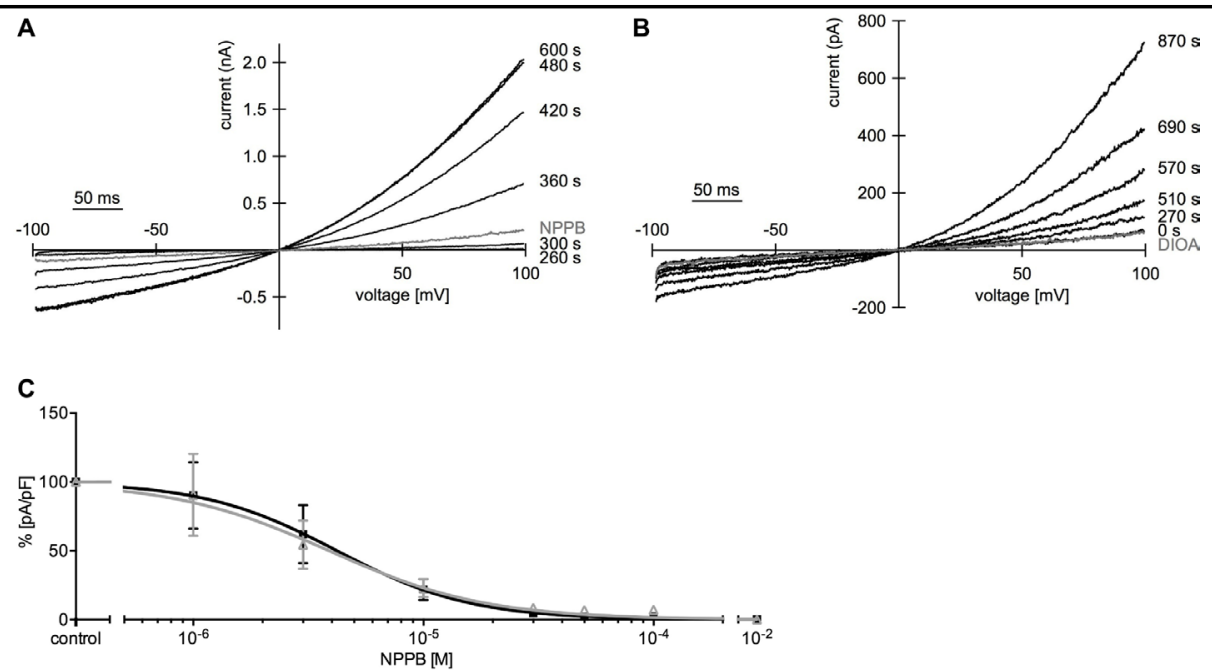

Fig. 1. Representative current tracings of whole cell patch clamp recordings of BV-2 cells at a holding potential of $0 \mathrm{mV}$. $\mathrm{I}_{\mathrm{cl} \text {, swell }}$ was evoked either by superfusion of a cell with (A) hypotonic solution (85\% of normal saline; $263 \mathrm{mosmol} / \mathrm{L}$ ) versus an isotonic intracellular solution (314 mosmol/L) or (B) by dialyzing the cell with a hypertonic intracellular solution ( $374 \mathrm{mosmol} / \mathrm{L})$ versus an isotonic extracellular solution. Symmetrical concentrations of intra- and extracellular $\mathrm{Cl}^{-}$were used and currents were monitored during $500 \mathrm{~ms}$ voltage ramps from $-100 \mathrm{mV}$ to $+100 \mathrm{mV}$. The current was suppressed by $100 \mu \mathrm{M} \mathrm{NPPB} \mathrm{(A)} \mathrm{and}$ $100 \mu \mathrm{M}$ DIOA (B). (C) Comparison of NPPB-dose-response curves in the inward (grey) and outward (black) direction of $\mathrm{I}_{\mathrm{Cl} \text {, swell }}$ fitted with the 4 parameter logistic equation by GraphPad Prism 4 under hypertonic intracellular conditions in control BV-2 cells. NPPB was used at 1, 3, 10, 30, 50 and $100 \mu \mathrm{M}$. Current data at -100 and $+100 \mathrm{mV}$ were obtained from $500-\mathrm{ms}$ voltage ramps and normalized to currents recorded under control conditions prior to the application of NPPB. Data are represented as mean \pm s.e.m. ( $n=3$ for each data point).

Fig. 2. Engulfment and attachment of hydrophobic polystyrene MBs by primary microglia and microglial cell line BV-2. (A) SEM of primary microglial cell with engulfed MBs at the soma and at the lamellipodia and attached spheres at the soma; (B) BV-2 cell with engulfed MBs at the soma of the cell and an attached sphere at the lamellipodia. Scale bars $20 \mu \mathrm{m}$.

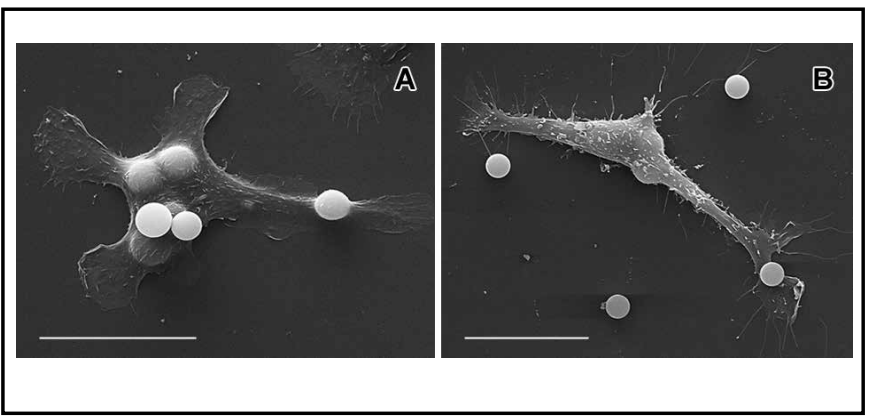

Fig. 3. Incubation in extracellular $\mathrm{Cl}$-free solution inhibited phagocytosis of MBs by the microglial cell line BV-2 after $1 \mathrm{~h}$ compared to extracellular solution (CO). Number of cells with successfully engulfed MBs was counted in three independent experiments and evaluated using SEM. Data are represented as mean \pm s.e.m.. Asterisks $(* *)$ indicate $\mathrm{P}<0.01$, when compared with control cells.

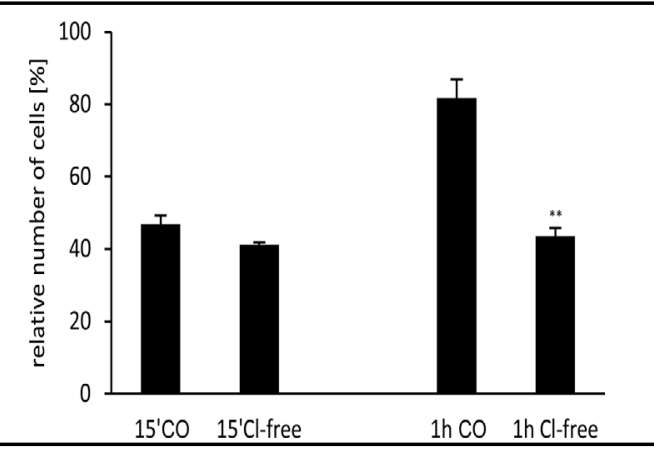

we counted distribution frequencies for BV-2 cells containing no MBs, one MB, two MBs and more than two MBs, respectively (Fig. 4B and C). After $15 \mathrm{~min}$ of exposure to MBs $53.2 \pm 2.5 \%$ did not contain a single MB, $28.0 \pm 1.1 \%$ contained one MB, $12.6 \pm 1.5 \%$ 


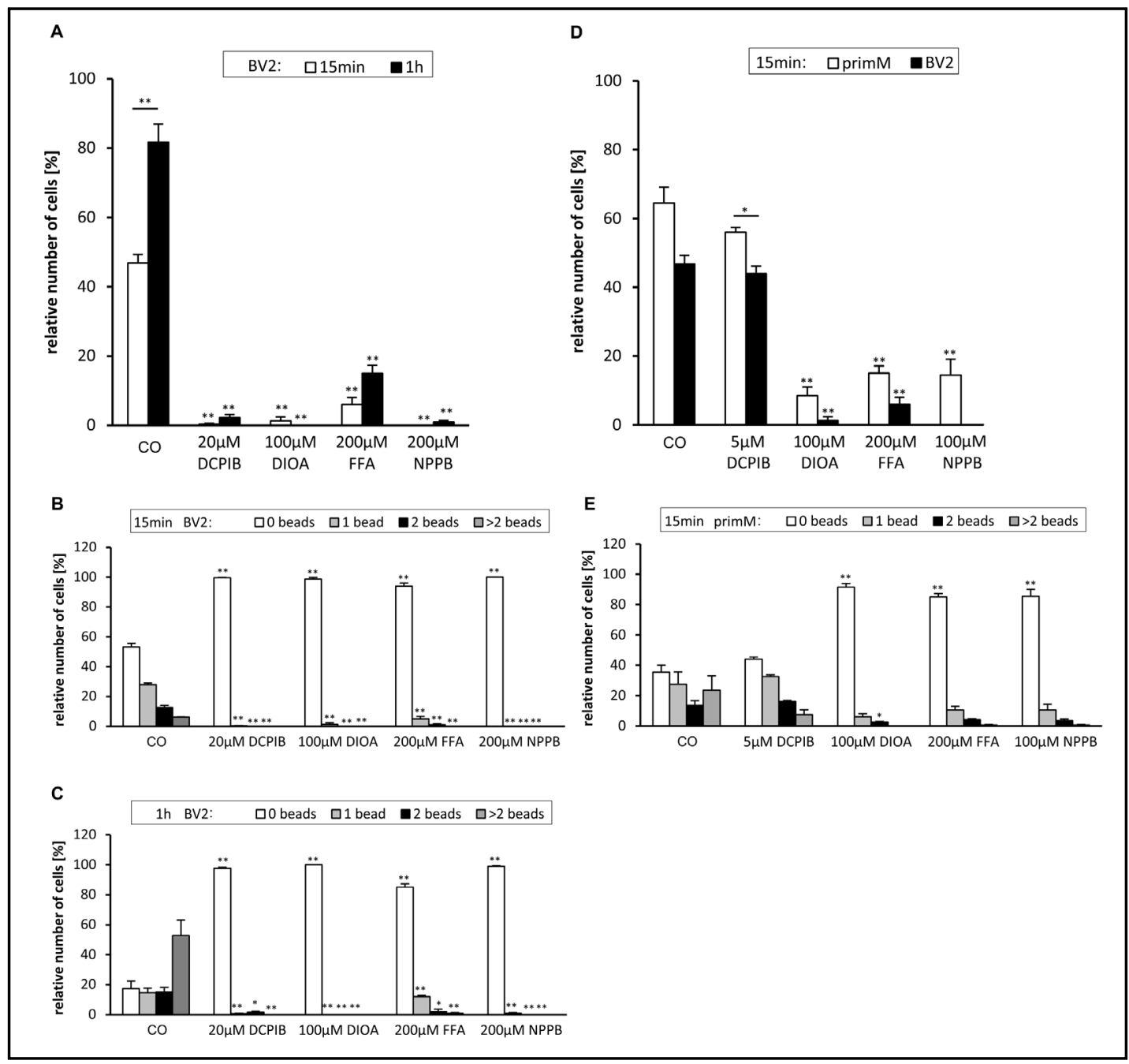

Fig. 4. Blockers of $\mathrm{I}_{\mathrm{Cl}, \text { swell }}$ inhibit phagocytosis of MBs by primary microglial cells (primM) and the microglial cell line BV-2. (A) Incubation of BV-2 cells with MBs for $15 \mathrm{~min}$ (white bars) and $1 \mathrm{~h}$ (black bars), respectively, in the absence and presence of anion channel blockers $(20 \mu \mathrm{M}$ DCPIB, $100 \mu \mathrm{M}$ DIOA, $200 \mu \mathrm{M}$ FFA, and $200 \mu \mathrm{M}$ NPPB). (B, C) Distribution frequency of MBs engulfed by BV-2 cells after $15 \mathrm{~min}(\mathrm{~B})$ and $1 \mathrm{~h}(\mathrm{C})$ of incubation in the absence and presence of inhibitors, respectively. (D) Phagocytotic capacity of primary microglial cells (primM; white columns) and microglial cell line BV-2 (BV2; black columns) in the absence (CO, control) and presence of anion channel blockers ( $5 \mu \mathrm{M}$ DCPIB, $100 \mu \mathrm{M}$ DIOA, $200 \mu \mathrm{M}$ FFA, and $100 \mu \mathrm{M}$ NPPB) after 15 min of incubation with MBs (in D data are absent for $100 \mu \mathrm{M}$ NPPB in BV-2 cells). (E) Frequency distribution of MBs engulfed by primM after 15 min of incubation in the absence and presence of inhibitors, respectively. (B, C and E) Number of cells with successfully engulfed MBs was counted in three independent experiments and evaluated using SEM. Data are represented mean \pm s.e.m.. Asterisks $\left({ }^{*},{ }^{* *}\right.$ ) indicate $\mathrm{P}<0.05, \mathrm{P}<0.01$, respectively, when compared with control cells or between two groups as marked by a line.

contained two MBs, and $6.2 \pm 0.2 \%$ contained more than two MBs. Incubation with 200 $\mu \mathrm{M}$ FFA revealed a distribution frequency of one or two spheres only, whereas treatment with $20 \mu \mathrm{M}$ DCPIB or $100 \mu \mathrm{M}$ DIOA revealed a net engulfment of only one sphere, and no uptake of microspheres was observed in microglia incubated with $200 \mu \mathrm{M}$ NPPB (Fig. 4B). After $1 \mathrm{~h}$ of exposure to MBs $52.8 \pm 10.3 \%$ of BV-2 cells had engulfed more than two MBs. The number of cells containing two, one, or no MBs was about $15 \%$ each (Fig. 4C). $85.0 \pm 2.4 \%$ of FFA-exposed $(200 \mu \mathrm{M}) \mathrm{BV}-2$ cells did not contain MBs, $12.0 \pm 0.9 \%$ contained 


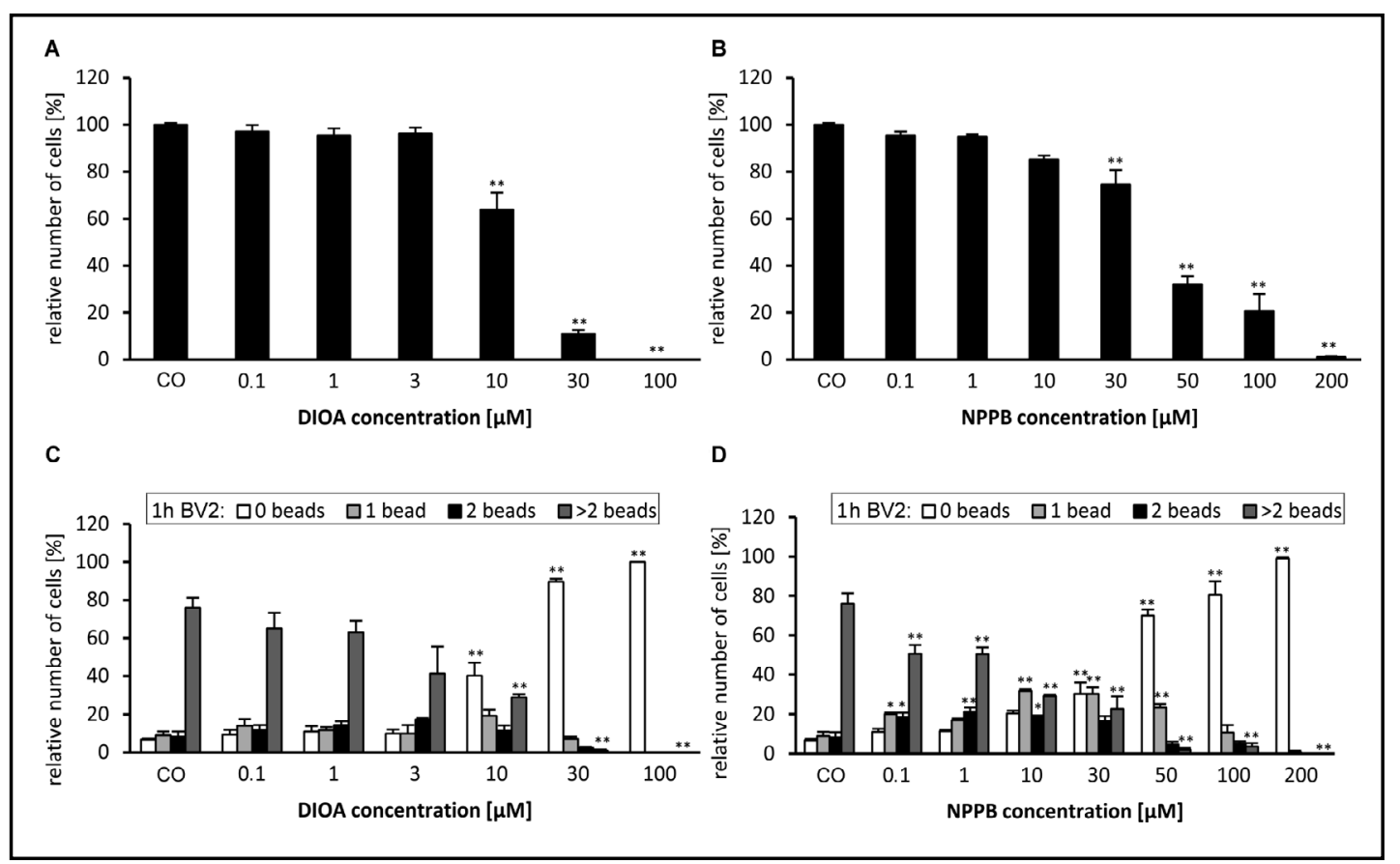

Fig. 5. The $\mathrm{K}^{+}-\mathrm{Cl}^{-}$-cotransporter blocker DIOA and the $\mathrm{Cl}^{-}$-channel blocker NPPB inhibited phagocytosis of MBs in a dose-dependent manner after incubation for $1 \mathrm{~h}$ in BV-2 cells. Phagocytosis at different blocker concentrations of DIOA (A) and NPPB (B) was normalized to control condition (CO), and each column represents the average of three independent experiments. (C, D) Frequency distribution of cells engulfing MBs shows that higher blocker concentrations increase the number of cells without engulfed MBs. Columns represent number of cells without phagocytosis (white columns), cells having successfully engulfed one MB (light grey columns), two MBs (black columns), and more than two MBs (dark grey columns). Number of cells with successfully engulfed MBs was counted in three independent experiments and evaluated using SEM. Data are represented as mean \pm s.e.m.. Asterisks $\left({ }^{*},{ }^{* *}\right)$ indicate $\mathrm{P}<0.05, \mathrm{P}<0.01$ when compared with control conditions.

one, $2.0 \pm 1.6 \%$ contained two and $1.0 \pm 0.5 \%$ more than two. $99.0 \pm 0.5 \%$ of cells incubated with NPPB $(200 \mu \mathrm{M})$ did not contain MBs and the remaining one percent contained one MB only, similar to DCPIB $(20 \mu \mathrm{M})$, where $97.6 \pm 0.8 \%$ of cells did not contain MBs. The remaining $\sim 2 \%$ is distributed among cells containing one and two MBs.

Primary microglial cells behaved slightly different from BV-2 cells. Under control conditions the overall number of primary microglial cells containing MBs was $64.5 \pm 4.6 \%$ (Fig. 4D). Again, in the presence of the inhibitors DIOA $(100 \mu \mathrm{M})$, FFA $(200 \mu \mathrm{M})$ and NPPB $(100 \mu \mathrm{M})$ the phagocytotic capacity was markedly depressed. At the single cell level only 35.5 $\pm 4.6 \%$ of primary microglial cells did not contain a single MB after 15 min of incubation. 27.5 $\pm 8.1 \%$ contained one MB, $13.5 \pm 3.2 \%$ two MBs and $23.5 \pm 9.5 \%$ more than 2 MBs (Fig. 4E). Incubation with DIOA $(100 \mu \mathrm{M})$, FFA $(200 \mu \mathrm{M})$ and NPPB $(100 \mu \mathrm{M})$ revealed a distribution frequency of $\sim 10 \%$ for cells containing one MB and $\sim 3 \%$ for cells with two MBs. The majority of cells ( $\sim 85 \%)$ did not contain a single MB (Fig. 4E). Since in primary microglia $20 \mu$ M DCPIB led to signs of apoptosis (see below), we tested its effect at the $I C_{50}$ for $\mathrm{I}_{\mathrm{cl} \text {, swell }}$, i.e. $5 \mu \mathrm{M}$. At this concentration DCPIB showed weak inhibitory effects: $32.5 \pm 1.1 \%$ of cells contained one MB, $16.0 \pm 0.7 \%$ contained two MBs and $7.8 \pm 3.2 \%$ contained more than two MBs. Only $44.0 \pm$ $1.4 \%$ of cells did not contain a MB (Fig. $4 \mathrm{E}$ ).

Inhibition of particle engulfment as well as block of $\mathrm{I}_{\mathrm{Cl} \text {, swell }}$ showed similarities in their concentration dependencies. DIOA and NPPB potently inhibited $\mathrm{I}_{\mathrm{cl} \text {, swell }}$ and effectively suppressed particle uptake in our study. For example, NPPB in the concentration range from 30 to $50 \mu \mathrm{M}$ suppressed MB uptake to $\sim 50 \%$ compared to control conditions and the $I C_{50}$ for 


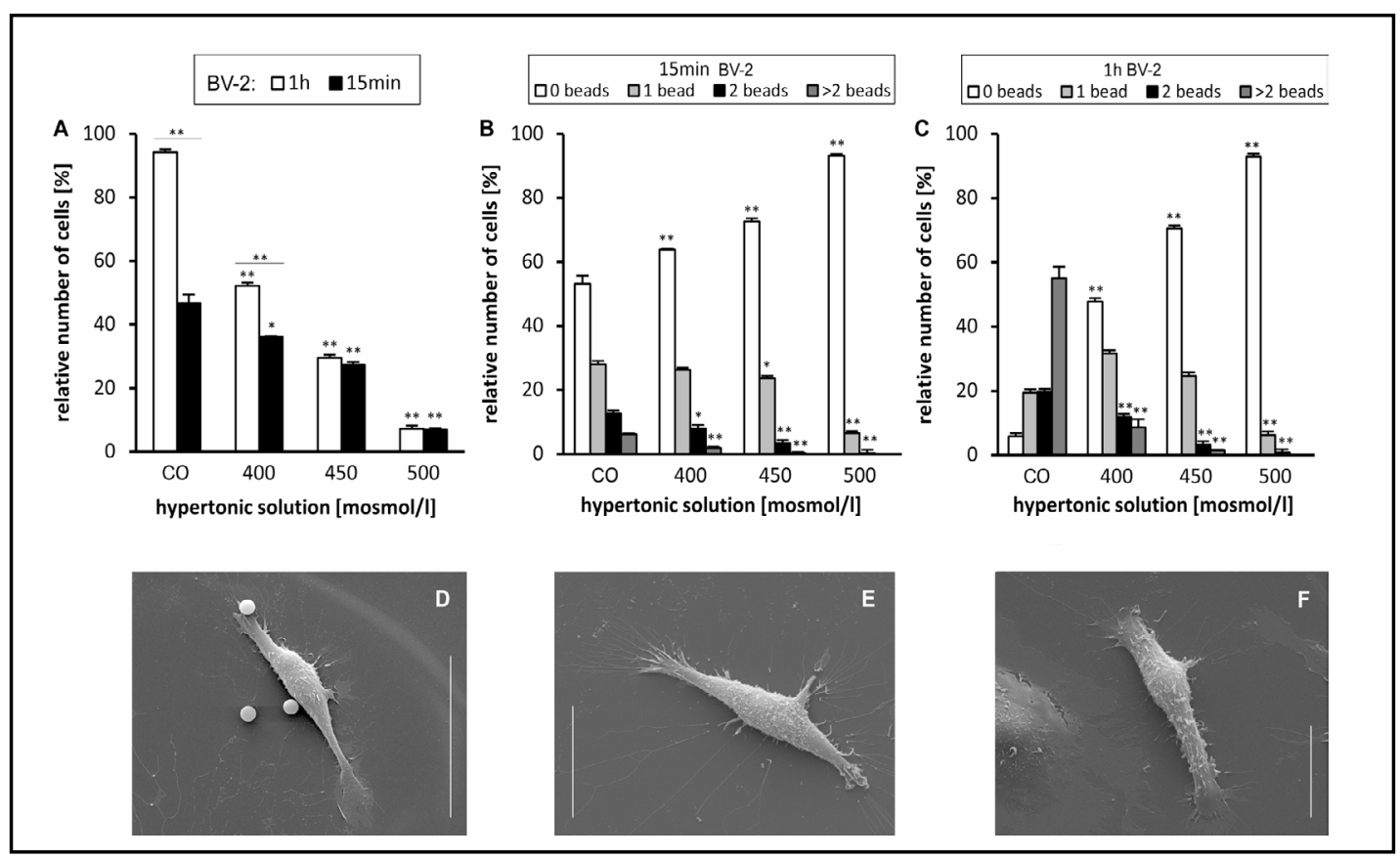

Fig. 6. Short-term hypertonicity inhibited phagocytosis of MBs by BV-2 cells. (A) BV-2 cells incubated with different concentrations of hypertonic solutions $(400,450$ and 500 mosmol/L) decreased phagocytosis of MBs after $15 \mathrm{~min}$ and $1 \mathrm{~h}$, respectively, compared to incubation in normotonic solution (CO). Hypertonicity decreased the frequency of MBs engulfed by microglial cells for $15 \mathrm{~min}$ (B) and $1 \mathrm{~h} \mathrm{(C),} \mathrm{respectively.} \mathrm{Columns}$ represent the relative number of cells without MBs (white columns), cells having successfully engulfed one MB (light grey columns), two MBs (black columns), and more than 2 MBs (dark grey columns). Cells with successfully engulfed MBs were counted in three independent experiments and evaluated using CLSM. (D-F) Representative SEM images of BV-2 cells incubated with extracellular hypertonic solutions: 400 mosmol/L (D), $450 \mathrm{mosmol} / \mathrm{L}$ (E), and $500 \mathrm{mosmol} / \mathrm{L}$ (F). Scale bars $20 \mu \mathrm{m}$ (E, F) and $40 \mu \mathrm{m}$ (D). Data are represented as mean \pm s.e.m.. Asterisks $(*, * *)$ indicate $\mathrm{P}<0.05, \mathrm{P}<0.01$, respectively, when compared with control conditions or between two groups marked by a line.

$\mathrm{I}_{\text {Cl, swell }}$ is $\sim 4 \mu \mathrm{M} .100 \mu \mathrm{M}$ DIOA and $100 \mu \mathrm{M}$ NPPB completely suppressed $\mathrm{I}_{\mathrm{Cl} \text {, swell }}$ (Fig. 1) and effectively blocked uptake of MBs (Figs. 4 and 5). DCPIB blocked $\mathrm{I}_{\mathrm{Cl} \text {, swell }}$ at concentrations of about $5 \mu \mathrm{M}$ (data not shown), but significantly suppressed particle uptake only at higher concentrations of about $20 \mu \mathrm{M}$ (Fig 4). In the frequency distribution a significant inhibition of cells able to phagocytose more than two beads can be observed at an NPPB concentration of $0.1 \mu \mathrm{M}$ (Fig. 5D). A similar observation was made for DIOA (Fig. 5C).

In electrophysiological experiments $\mathrm{Cl}^{-}$-currents with biophysical and pharmacological properties similar to $\mathrm{I}_{\mathrm{Cl} \text {, swell, }}$, but induced by increased intracellular $\mathrm{Ca}^{2+}$ or cAMP in contrast to cell swelling, are terminated by superfusion with hyperosmotic extracellular solutions [21]. In our engulfment experiments we used a similar approach; BV-2 cells were exposed to hyperosmotic conditions $(400,450$ and $500 \mathrm{mosmol} / \mathrm{L}$, respectively) for $15 \mathrm{~min}$ or $1 \mathrm{~h}$ and uptake of MBs was quantified using CLSM. Suppression of MB uptake increased with the osmolarity of the extracellular solution (Fig. 6A). Under control conditions, the frequency distribution of cells containing none, one, two, or more than two MBs differed between cells exposed to MBs for $15 \mathrm{~min}$ and $1 \mathrm{~h}$, respectively. Cells exposed for $15 \mathrm{~min}$ showed a frequency distribution pattern in which cells containing no MB dominated (Fig. 6B), but after $1 \mathrm{~h}$ most cells contained more than two MBs. The number of cells containing at least one $\mathrm{MB}$ decreased with increasing extracellular osmolarity, but did not differ between cells exposed to 450 or $500 \mathrm{mosmol} / \mathrm{L}$ for $15 \mathrm{~min}$ or $1 \mathrm{~h}$. On the other hand, comparing frequency distribution of cells incubated with the lowest hypertonic osmolarity 
Fig. 7. The $\mathrm{Cl}^{-}$-channel blocker DCPIB delays RVD. After incubation of cells in normotonic saline (CO), cells were exposed to hypotonic solution $(200$ mosmol/L) in the absence (CO) or presence of $5 \mu \mathrm{M}$ DCPIB or $200 \mu \mathrm{M} F F A$, respectively. Cells exposed to DCPIB showed a higher cell volume (CV) increase and a delayed RVD compared to cells exposed to hypotonic solution alone. CV was evaluated by flow cytometry as FSC-A for three independent experiments. Data are represented as mean \pm s.e.m..

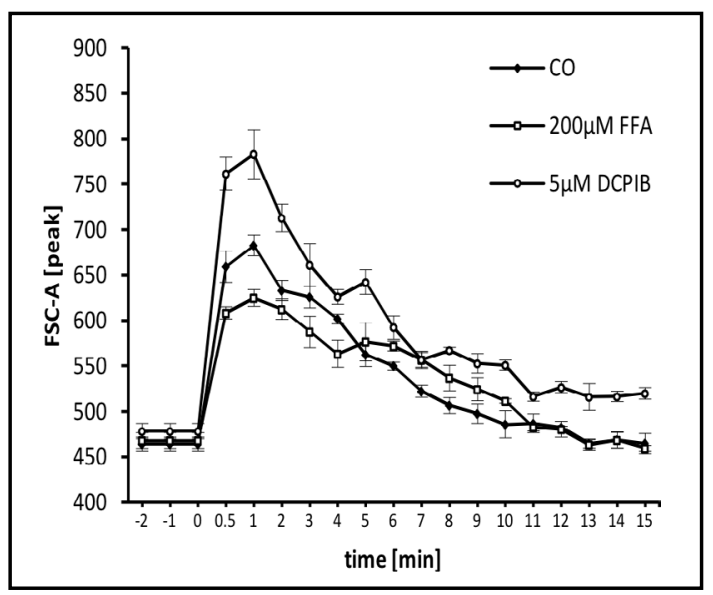

(400 mosmol/L) revealed a significant decrease in cells without MBs and a significant increase in cells containing two MBs when compared between $15 \mathrm{~min}$ and $1 \mathrm{~h}$, respectively (Fig. 6B, C). Although hyperosmotic extracellular solutions significantly suppressed uptake of MBs, SEM revealed that the cells did not exhibit a shrunken morphology (Fig. 6D, E, F), indicating efficient volume regulatory processes in these cells. Thus, similar to the suppression of $\mathrm{Cl}^{-}$-currents induced in normotonic solutions by intracellular $\mathrm{Ca}^{2+}$ or cAMP, hyperosmotic extracellular solutions suppressed engulfment of MBs. These experiments suggest that ion conductances required for $\mathrm{CV}$ regulation, like the $\mathrm{Cl}^{-}$-conductance, are also involved in particle uptake.

Next, we evaluated whether the low number of engulfed MBs in cells exposed to $\mathrm{Cl}^{-}-$ channel blockers was due to inhibition of engulfment or due to less accessibility to MBs, like, e.g., by a decrease in cell migration. We assumed that no change or even an increase in the number of attached MBs, but a decrease in the number of engulfed MBs, indicated an inhibition of the engulfment process. We added $3.41 \times 10^{6}$ MBs per dish $\varnothing \varnothing$ of dish: $3.5 \mathrm{~cm}$ ). Assuming a statistically even distribution of MBs, $\sim 2$ MBs were present per 500 $\mu \mathrm{m}^{2}$. Accordingly, a cell with a length of $60 \mu \mathrm{m}$ had about $45 \mathrm{MBs}$ within an area with a diameter twice of its length as potential targets. The ratio of engulfed to attached particles was balanced in control conditions to 1:0.9. Microglial cells incubated with $\mathrm{Cl}^{-}$-channel blockers had more particles attached than engulfed. The relative distribution of engulfed to attached particles in cells treated with DCPIB $(20 \mu \mathrm{M})$, DIOA $(100 \mu \mathrm{M})$ and FFA $(200 \mu \mathrm{M})$ was 1:2.2, 1:4.4 and 1:1.5, respectively. Cells treated with NPPB $(200 \mu \mathrm{M})$ did not contain MBs, however, on average 1.6 MBs were attached to the cell surface. These observations support the assumption that $\mathrm{Cl}^{-}$-channel blockers interfere with the engulfment process and do not limit accessibility of the cell to the MBs. Furthermore, $\mathrm{Cl}^{-}$-conductance inhibition does not prevent MB attachment, but suppresses extension of engulfment pseudopodia.

Hypotonic challenges of $\sim 70 \%$ (extracellular $200 \mathrm{mosmol} / \mathrm{L}$ ) induced cell swelling in BV-2 cells. Under control conditions CV increased within 1 min by $~ 46 \%$ and cells re-gained their initial CV within 13 min by RVD. In the presence of DCPIB ( $5 \mu \mathrm{M}) \mathrm{CV}$ increased by $\sim 63 \%$, i.e. $\sim 15 \%$ more than in absence of the inhibitor, and RVD was incomplete within 15 min. In the presence of FFA $(200 \mu \mathrm{M}) \mathrm{CV}$ increased by $\sim 33 \%$ and cells regulated back to their initial CV within 13 min (Fig. 7).

Since $\mathrm{Cl}^{-}$-channel blockers may have toxic effects, we evaluated cell blebbing, a hallmark of apoptosis, using SEM. About 300-600 cells in three independent experiments were evaluated in the presence or absence of $\mathrm{Cl}^{-}$-channel blockers. In the absence of $\mathrm{Cl}^{-}$-channel blockers we did not observe cells with blebs. Similarly, exposure of cells for 15 min to DCPIB $(5 \mu \mathrm{M}$ ), FFA (up to $200 \mu \mathrm{M}$ ), and NPPB (up to $200 \mu \mathrm{M}$ ) did not reveal cells containing blebs. However, DIOA $(100 \mu \mathrm{M})$ and DCPIB $(20 \mu \mathrm{M})$ increased the number of blebbing cells to $10.6 \pm 4.1 \%$ and $19.9 \pm 2.4 \%$ within 15 min and to $60.7 \pm 12.5 \%$ and $47.0 \pm 14.8 \%$ within 
Harl/Schmölzer/Jakab/Ritter/Kerschbaum: Chloride Channel Blockers Suppress

Fig. 8. (A, B) Representative cells treated with DCPIB $(20 \mu \mathrm{M})$ showing blebbing, a hallmark of apoptosis visualized by SEM. Arrows point to cells with blebbing. Scale bars $100 \mu \mathrm{m}$ (A) and $20 \mu \mathrm{m}(\mathrm{B})$.

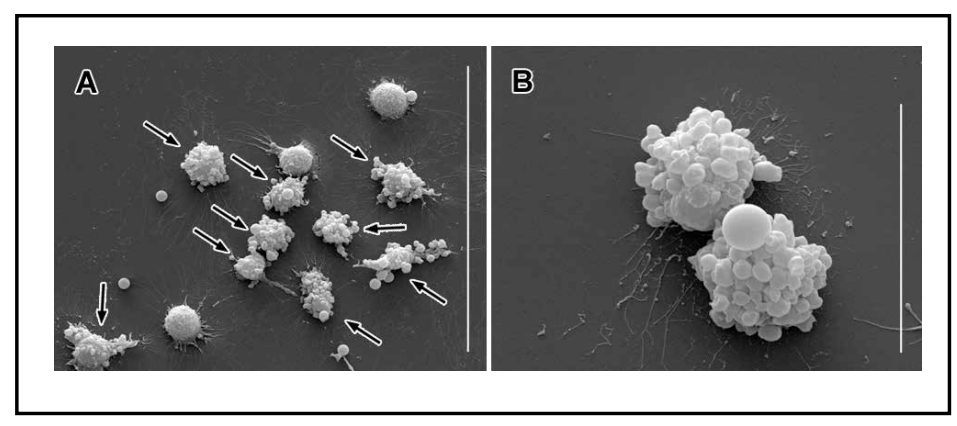

Fig. 9. Scanning electron microscopy of microglial BV-2 cells with successive engulfment of a hydrophobic polystyrene MB at the soma of a cell. (A) The $M B$ is attached to the soma of a microglial cell. (B) Numerous fine protrusions extend from the cell surface at the contact area between the microglial cell and the MB. These nascent protrusions are tightly fitting the MB. (C) Protrusions augment on the base to flat, broad extensions, engulfing the MB. (D) Processes extend continuously, fusing together to an area with fine protrusions distally, engulfing more than $2 / 3$ of the MB. Simultaneously internalization can be observed. (E) The MB is completely enclosed by the cell membrane. At the area of process contact, engulfing processes overlap and melt together. (F) Engulfment and internalization is
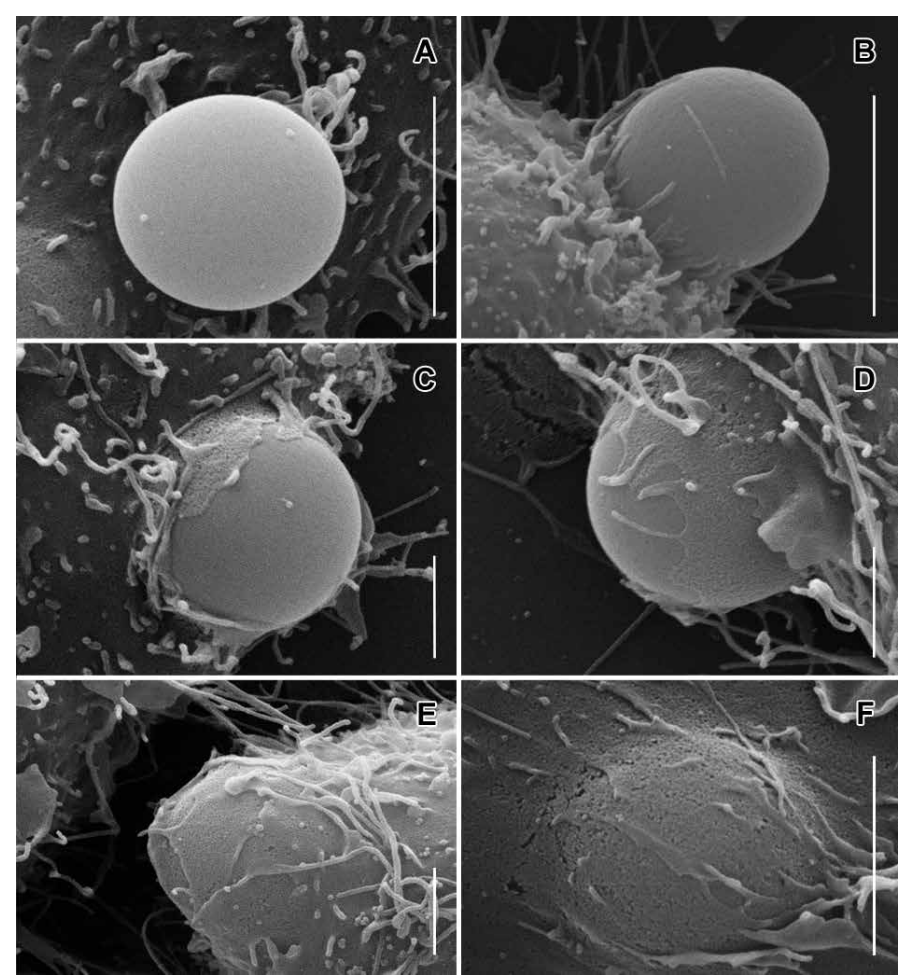

accomplished. The MB is subsided into the cell and only the shape of it can be seen on the cell surface. Scale bars $2 \mu \mathrm{m}(\mathrm{C}-\mathrm{E})$ and $4 \mu \mathrm{m}(\mathrm{A}, \mathrm{B}, \mathrm{F})$.

$1 \mathrm{~h}$, respectively. Thus, among the $\mathrm{Cl}$-channel blockers used, DIOA and DCPIB considerably increased the number of cells showing blebs. Figures $8 \mathrm{~A}$ and $\mathrm{B}$ visualize representative cells with blebbing DCPIB $(20 \mu \mathrm{M})$. Since DIOA blocks $\mathrm{Cl}^{-}$-channels $[3,22]$ as well as KCC [3, 22-26], these may cause an imbalance in $\mathrm{Cl}^{-}$or intracellular $\mathrm{pH}$ homeostasis, because $\mathrm{Cl}^{-}$ channels and transporters are also permeable to $\mathrm{HCO}_{3}^{-}[9,27]$.

\section{Cl-channel blockers suppress formation of engulfment pseudopodia}

As mentioned above, pseudopodia formation and the following particle engulfment take place all over the cell body and are not restricted to the lamellipodium (Fig. 2A, B). SEM images visualized two modes of MB uptake: (i) Contact of a particle with the plasma membrane initialized formation of an engulfment pseudopodium. This tight fitting pseudopodium extended along the particle and fused at the top of the MB. In parallel to fusion of engulfment pseudopodia the particle was descended into the cell soma (Fig. 9). (ii) Delicate, filopodia-like protrusions extended from the cell surface and transformed to 
Harl/Schmölzer/Jakab/Ritter/Kerschbaum: Chloride Channel Blockers Suppress Phagocytosis

Fig. 10. Scanning electron microscopy of microglial BV-2 cells showing successive engulfment of hydrophobic polystyrene $\mathrm{MB}$ at the lamellipodia of a cell. (A) The MB is attached to a lamellipodia of a microglial cell. (B) Fine protrusions from the cell surface contact the MB, augmenting to a broad, flat engulfing area between the cell and the MB. (C) Engulfing extensions envelop tightly half of the MB. (D) Almost the whole MB is engulfed by the cell. Extending engulfing areas laterally overlap; only a blank space between the engulfing processes is left. (E) The MB is completely engulfed by the cell. Overlapping engulfing processes melt together on area of contact. (F) The MB is internalized by microglial cell surface. The shape of the MB can be seen on the lamellipodia of the microglial cell. Scale bars $2 \mu \mathrm{m}$ (D, E) and $4 \mu \mathrm{m}(\mathrm{A}-\mathrm{C}, \mathrm{F})$.

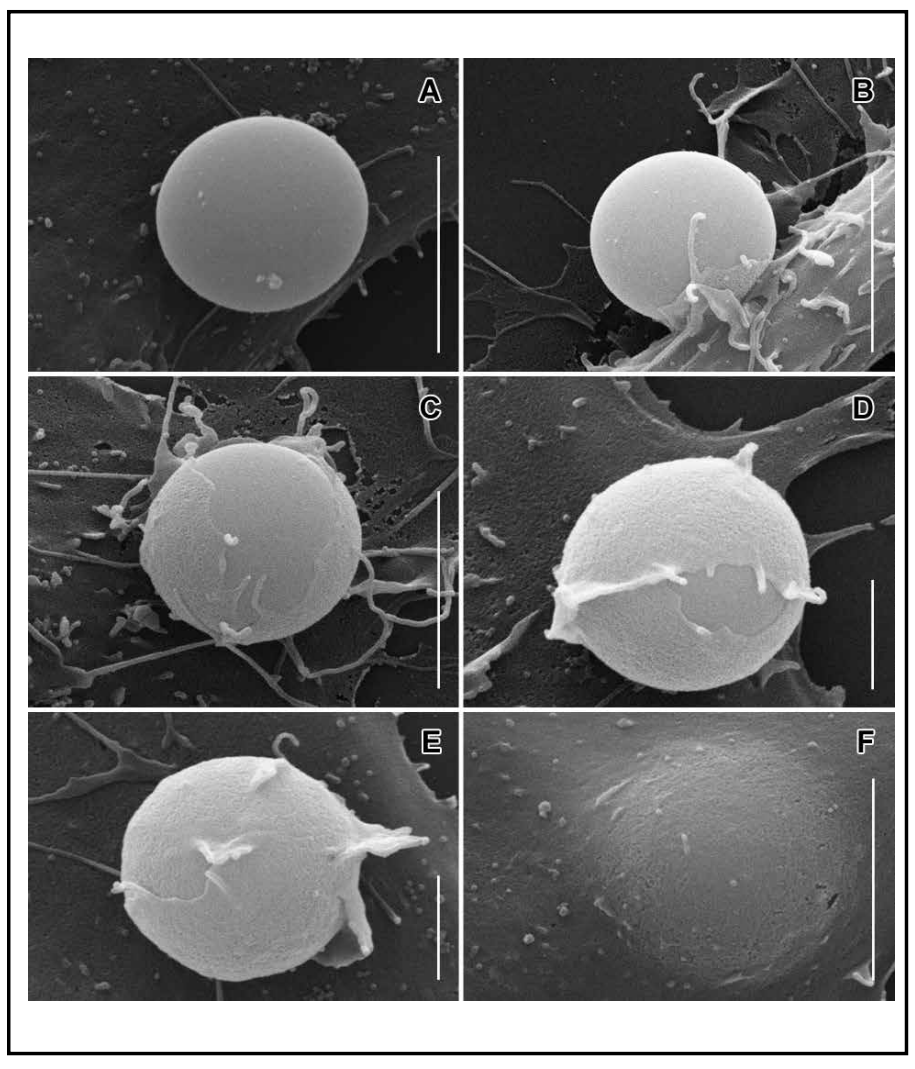

Fig. 11. Attachment of hydrophobic polystyrene MBs by microglial BV-2 cell. Scanning electron microscopy of microglial cells exposed to different anion channel blockers, i.e., $5 \mu \mathrm{M}$ DCPIB (A), $100 \mu \mathrm{M}$ DIOA (B), $200 \mu \mathrm{M}$ FFA (C), and $200 \mu \mathrm{M}$ NPPB (D). Scale bars $4 \mu \mathrm{m}$.

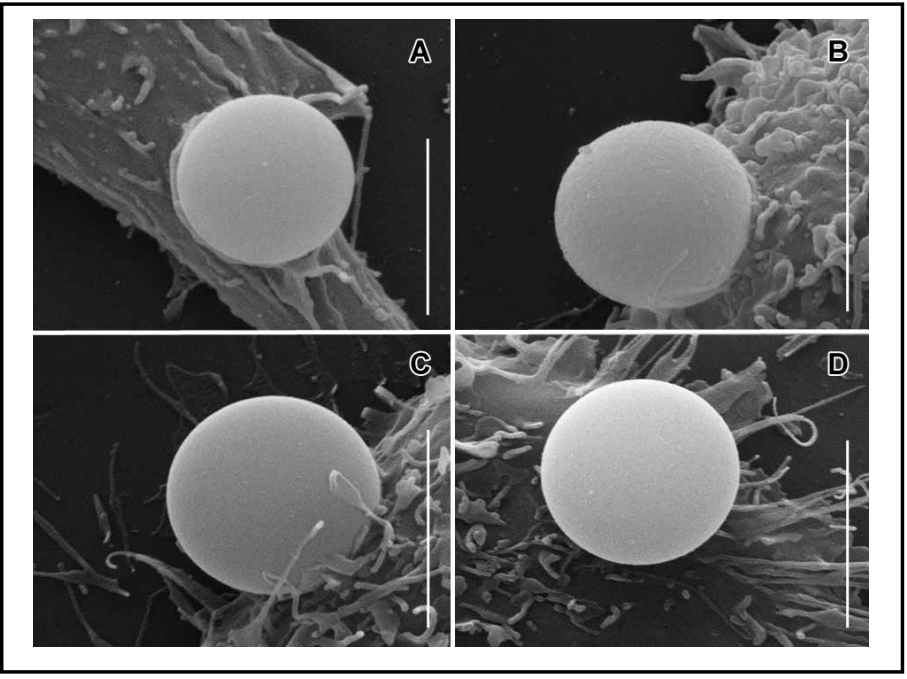

flat engulfing pseudopodia. These extending engulfing areas followed the contour of the particle, overlapped at the area of contact and fused with each other. In contrast to mode one, particles were not invaginated, but protruded above the cell surface (Fig. 10).

Cells exposed to $\mathrm{Cl}^{-}$-channel blockers behaved differently (Fig. 11); in contrast to control conditions, under these conditions cells failed to extend engulfment pseudopodia. Accordingly, fewer MBs are engulfed (Fig. 4). However, cells exposed to MBs in nominally $\mathrm{Cl}^{-}-$ free conditions revealed formation of lamellipodia and filopodia similar to control conditions despite their attenuated phagocytotic capacity (Fig. 3). This may indicate that swellingactivated $\mathrm{Cl}^{-}$-channels are not selective to $\mathrm{Cl}^{-}$, but are also permeable for other anions. 
A

- cell without MB
- cell with MB

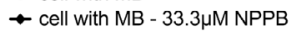

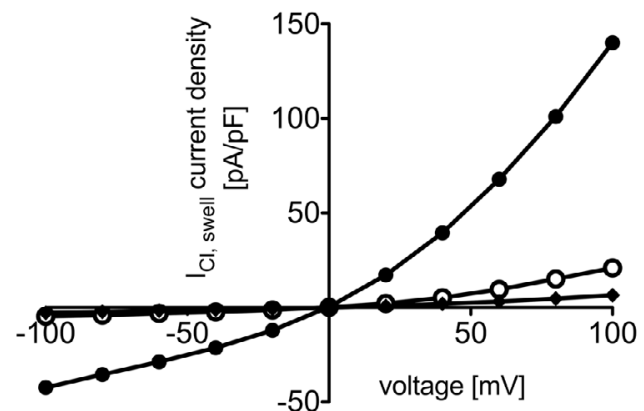

D

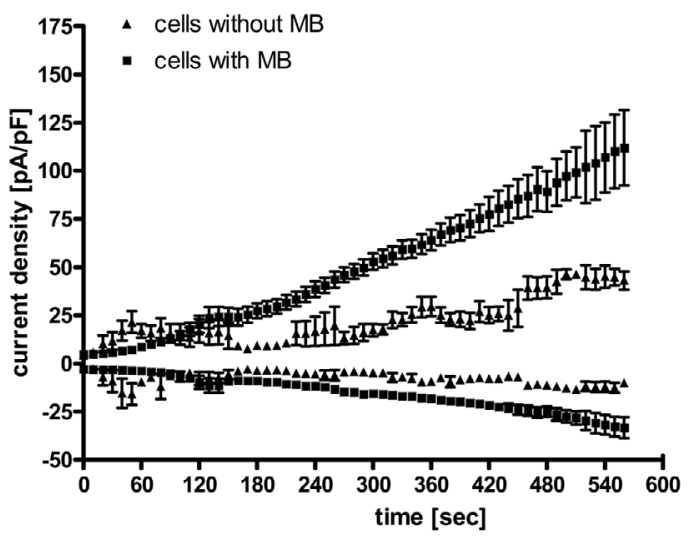

B

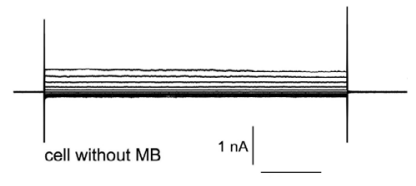

c
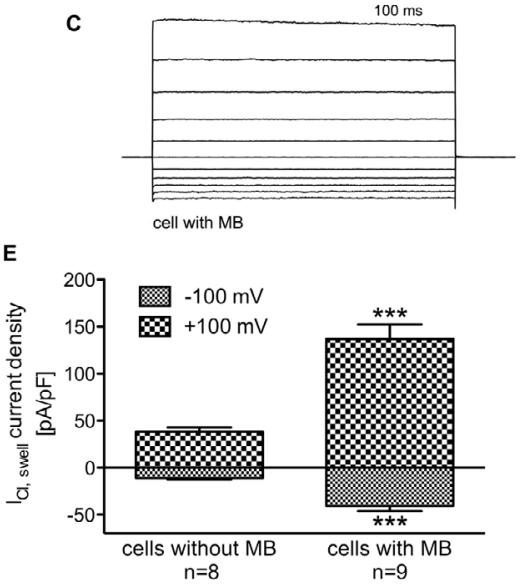

$F$

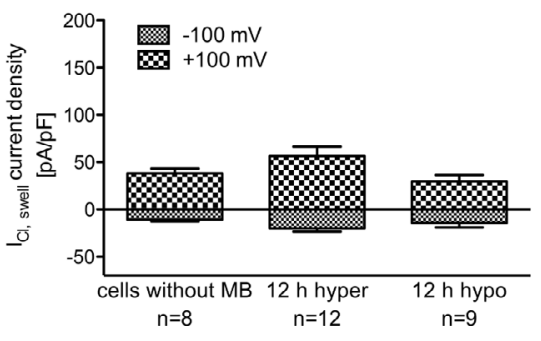

Fig. 12. Whole cell patch clamp technique was used to characterize anion currents evoked by dialyzing BV-2 cells with hypertonic (374 mosmol/L) internal solution versus an external isotonic solution (308 mosmol/L). (A) Maximally activated $\mathrm{I}_{\mathrm{Cl} \text {, swell }}$ of a cell containing at least three MBs (cell with MB, closed circles) and a cell without MB (open circles) in response to voltage-steps from -100 to $+100 \mathrm{mV}$ with 20 -mV increments as shown in (B) and (C), respectively. Note the higher current amplitudes in the cell containing MBs. The current of the cell with MBs could be completely blocked with $33.3 \mu$ M NPPB (closed diamonds). (D) Activation curves of the inward $(-100 \mathrm{mV})$ and outward $(+100 \mathrm{mV})$ current over time obtained from 500 ms voltage ramps from -100 to $+100 \mathrm{mV}$ at 10 -sec intervals in cells with (rectangles; $\mathrm{n}=5-9$ ) and without MB (triangles; $\mathrm{n}=2-8$ ). Time point zero is the start of the superfusion with external isotonic solution (308 mosmol/L). (E) Maximally activated current of BV-2 cells without and with MBs. Control cells without MB are denoted as 'cells without MB'. (F) Long-term osmotically stressed cells were cultured for 12-16 h in hypertonic (400 mosmol/L) or hypotonic (200 mosmol/L) culture medium plus serum and are denoted as ' 12 h hyper' and ' $12 \mathrm{~h}$ hypo', respectively. Data are represented as mean \pm s.e.m.. Asterisks (***) indicate $\mathrm{P}<0.001$. The numbers of individual experiments are depicted in the figure.

\section{Particle uptake causes an increase in $\mathrm{Cl}$-conductance}

In hepatocytes, glucagon-induced catabolic processes are associated with an increase in $\mathrm{Cl}^{-}$-conductance [15]. Accordingly, we expected an increase in $\mathrm{I}_{\mathrm{Cl}, \text { swell }}$ in microglial cells, because phagocytes degrade internalized particles, or because of an increase in the cell's volume if non-digestible particles accumulate within the cell. In our study, uptake of each MB with a diameter of $4 \mu \mathrm{m}$ added $\sim 34 \mu \mathrm{m}^{3}$ to the CV. BV-2 cells were exposed to MBs for $\sim 300$ min, and $\mathrm{I}_{\mathrm{cl} \text {, swell }}$ was subsequently measured. As shown in Figure 12, the kinetic of current development (Fig. 12D) and the maximum current density (Fig. 12E) measured in cells containing at least three MBs significantly differed from control cells without MBs. The 


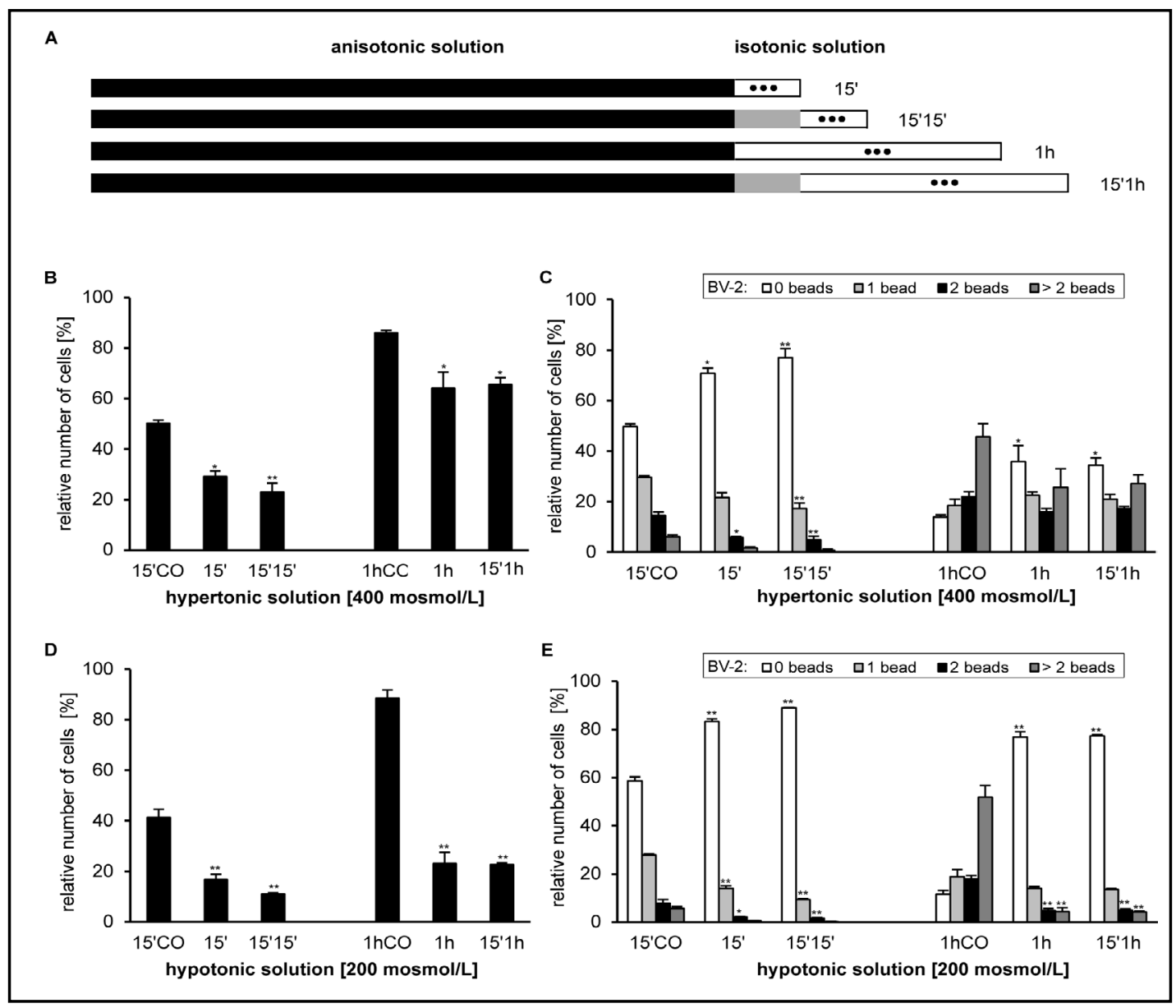

Fig. 13. Long-term hypertonicity and hypotonicity inhibited phagocytosis of MBs by microglial cell line BV-2. (A) Timetable as schematic illustration of cell procedure in anisotonic conditions. After culture of microglia for $12 \mathrm{~h}$ in anisotonic conditions (black bars), cells were exposed for $15 \mathrm{~min}\left(15^{\prime}\right)$ or $1 \mathrm{~h}(1 \mathrm{~h})$ in isotonic saline in the presence of MBs (white bars with black spheres). Another group of cells was exposed for $15 \mathrm{~min}$ in isotonic saline alone (grey bars) before addition of MBs to isotonic saline for $15 \mathrm{~min}$ (15'15') or $1 \mathrm{~h}\left(15^{\prime} 1 \mathrm{~h}\right)$. Microglial cells cultured in hypertonic solution (B) and hypotonic solution (D) decreased phagocytosis of MBs after $15 \mathrm{~min}$ and $1 \mathrm{~h}$, respectively, compared to incubation in extracellular solution (CO). Control groups were cultured in isotonic saline for $12 \mathrm{~h}$ and incubated for $15 \mathrm{~min}$ (15'CO) with MBs. Frequency distribution of microglial cells with phagocytosed MBs after culture in hypertonic (C) or hypotonic (E) solution are shown as columns representing the number of cells without MBs (white columns), cells successfully engulfed 1 MB (light grey columns), 2 MBs (black columns), and more than 2 MBs (dark grey columns). The number of cells with successfully engulfed MBs was counted in 3 independent experiments and evaluated using SEM. Data are represented as mean \pm s.e.m.. Asterisks $(*, * *)$ indicate $\mathrm{P}<0.05, \mathrm{P}<0.01$ when compared with appropriate control groups.

slope of inward and outward current activation was steeper and the current density after $\sim 9$ min was approximately 2-fold higher in phagocytizing cells. Similar to $\mathrm{I}_{\mathrm{Cl} \text {, swell }}$ in control cells, the current in cells containing MBs was outwardly rectifying. Current densities of maximally activated $\mathrm{I}_{\mathrm{Cl} \text {, swell }}$ were $136.8 \pm 15.4$ and $-40.7 \pm 5.5 \mathrm{pA} / \mathrm{pF}$ at +100 and $-100 \mathrm{mV}$ in cells containing MBs versus $38.0 \pm 4.9$ and $-11.0 \pm 1.6 \mathrm{pA} / \mathrm{pF}$ in cells without $\mathrm{MBs}$. The $\mathrm{Cl}^{-}-$ current in cells containing MBs was sensitive to NPPB (Fig. 12 A), DIOA, FFA and DCPIB (data not shown). These findings indicate that particle engulfment up-regulates ion channels for $\mathrm{I}_{\mathrm{Cl} \text {, swell }}$ in the plasma membrane of BV-2 cells. 
Pre-conditioning of BV-2 cells in hypotonic or hypertonic medium attenuates microsphere uptake

If the observed up-regulation of $\mathrm{I}_{\mathrm{Cl}, \text { swell }}$ is a consequence of an increase in CV or, comparably, an increase in intracellular osmotic pressure following degradation of a digestible particle, long-term osmotic challenges might affect phagocytotic capacity. Accordingly, we assumed that anisotonic pre-conditioning, which has been reported to alter the set point for CV regulation in different cell types [8], might modulate particle uptake. Figure 13A shows the schedule of our experiments. Cells were exposed to hypo- (200 mosmol/L) or hypertonic ( $400 \mathrm{mosmol} / \mathrm{L}$ ) conditions for $12 \mathrm{~h}$. Then they were allowed to undergo post-RVD RVI and post-RVI RVD, respectively, in normotonic conditions for $15 \mathrm{~min}$. BV-2 cells were exposed to $\mathrm{MBs}$ in normotonic conditions for $15 \mathrm{~min}$ or $1 \mathrm{~h}$. In some experiments, cells were first adapted to normotonic conditions for $15 \mathrm{~min}$ and then exposed to MBs for $15 \mathrm{~min}$ or $1 \mathrm{~h}$. We did not observe significant alterations in $\mathrm{I}_{\mathrm{Cl} \text { swell }}$ magnitude in BV-2 cells pre-exposed to hypotonic or hypertonic conditions (Fig. 12F). However, a significant decrease of MB uptake upon hypo-, or hypertonic pre-conditioning was detectable (Fig. 13). Cells cultured for 12 $\mathrm{h}$ in hypotonic and hypertonic conditions, respectively, revealed a decrease in phagocytosis of MBs. Cells conditioned in hypertonic medium showed a decrease by about $21 \%$ after incubation with MBs for $15 \mathrm{~min}$ and $1 \mathrm{~h}$, respectively (Fig. 13B). At the single cell level, the decrease in MB uptake was visualized by an increase in the number of cells without MBs and a decrease in the number of cells containing MBs (Fig. 13C). Cells conditioned in hypotonic culture medium showed a decrease by $\sim 30 \%$ after $15 \mathrm{~min}$ or by $\sim 65 \%$ after $1 \mathrm{~h}$ compared to cells cultured in control medium (Fig. 13D). There was no difference between phagocytosis of cells exposed directly to isotonic solution or cells pre-incubated in isotonic solution for $15 \mathrm{~min}$ before addition of MBs. The frequency distribution revealed that after $15 \mathrm{~min}$ about $60 \%$ of cells did not contain a single MB, $\sim 30 \%$ contained one and less than $10 \%$ two or more than two MBs. After $1 \mathrm{~h}$, the majority of cells contained more than two MBs, and the minority contained no MB in control conditions (Fig. 13E).

\section{Discussion}

Our findings indicate changes in $\mathrm{Cl}^{-}$-conductance in an early phase of phagocytosis as well as hours after particle uptake. In an early phase, the increase in $\mathrm{Cl}^{-}$-conductance is essential for formation of engulfment pseudopodia. The late phase changes in $\mathrm{Cl}^{-}$-conductance may be related to similarities between phagocytosis and osmoregulation. Both rely on the activation of a $\mathrm{Cl}^{-}$-conductance and osmotic challenges modulate particle uptake.

Early consequences of $I_{C l, \text { swell }}$ activation on phagocytosis

The earliest morphological change following contact between the phagocyte and a potential target is the formation of an engulfment pseudopodium. In the present study, we tie changes in $\mathrm{Cl}^{-}$-conductance to engulfment pseudopodium formation. Changes in ion conductance in phagocytes following contact with a particle are a common phenomenon [28-31]. Cell-attached recordings from human macrophages during particle ingestion reveal inward and outward single channel currents, carried by $\mathrm{Cl}^{-}$and $\mathrm{K}^{+}$-ions, respectively [30]. Since an inward $\mathrm{Cl}^{-}$-current represents an efflux of $\mathrm{Cl}^{-}, \mathrm{K}^{+}$as well as $\mathrm{Cl}^{-}$leaves the cell. Similarly, in human PMNs, phagocytosis of opsonized Candida albicans induces a $\mathrm{Cl}^{-}$-efflux [1]. Furthermore, in microglial cells and PMNs, application of $\mathrm{Cl}^{-}$-channel blockers suppresses engulfment of polystyrene MBs, E. coli, S. aureus, or C. albicans [2-4, and present study]. As shown in Figure 3, phagocytosis in microglia is a chloride dependent process. Since phagocytosis leads to cell swelling, we focused in the present study on swelling activated $\mathrm{Cl}^{-}$-current $\left(\mathrm{I}_{\mathrm{Cl} \text {, swell }}\right)$. Activation of $\mathrm{I}_{\mathrm{Cl} \text {, swell }}$ is due to an osmotic imbalance, like hypotonic extracellular or hypertonic intracellular conditions [8,32]. However, a $\mathrm{Cl}^{-}$-conductance with a similar electrophysiological and pharmacological signature is also activated in normotonic conditions via an increase in intracellular $\mathrm{Ca}^{2+}$ or cAMP and elevated PKA activity or 
stimulation of exchange proteins directly activated by cAMP (Epac) [15, 21, 33-36]. Thus, contact between a particle and a phagocyte could trigger an intracellular signalling cascade, which activates $\mathrm{Cl}^{-}$-channels in microglial cells, even at normotonic conditions. We found that formation of engulfment pseudopodia is prevented by blockade of $\mathrm{I}_{\mathrm{cl}, \text { swell }}$ : Thus, the most important function of $\mathrm{I}_{\mathrm{Cl} \text {, swell }}$ activation in the early phase of phagocytosis is its contribution to the formation of engulfment pseudopodia. Failure of engulfment pseudopodia formation prevents uptake of particles.

$\mathrm{I}_{\mathrm{Cl} \text {, swell }}$ is more sensitive to $\mathrm{Cl}^{-}$-channel blockers than the phagocytotic activity. For example, in our experiments $\sim 4 \mu \mathrm{M}$ NPPB were required to block half of $\mathrm{I}_{\mathrm{cl} \text {, swell }}$ (Fig. 1), whereas about $\sim 40 \mu \mathrm{M}$ were necessary to suppress the overall MB uptake to $50 \%$ (Fig. 5B). However, a significant inhibition of cells able to phagocytose more than two MBs can be already observed at an NPPB concentration of $0.1 \mu \mathrm{M}$ and the estimated $I C_{50}$ for this phenomenon is $\sim 10 \mu \mathrm{M}$ (Fig. 5D), which corresponds to the $I C_{75}$ for NPPB of $\mathrm{I}_{\mathrm{Cl} \text {, swell }}$ (Fig. 1). This indicates on the one hand the exquisite dependency of phagocytosis on Cl-channels. On the other hand it raises the interesting question about the number of $\mathrm{Cl}^{-}$-dependent pathways, like $\mathrm{Cl}^{-}$-channels, which are required to initiate and maintain phagocytosis. Although we cannot answer this question it is tempting to speculate that a surplus of $\mathrm{Cl}^{-}$channels is required for multiple uptake of MBs or for counterbalancing the increase in CV or osmotic pressure (see below).

Lamellipodia of migrating cells and engulfment pseudopodia of phagocytes share morphological and structural similarities, which may be rooted to similarities in their genesis. Specifically, in both structures swelling-activated $\mathrm{Cl}^{-}$channels may contribute to local ion movements establishing local changes in CV. In migrating cells, ion pathways serving for local cell shrinkage (RVD), like e.g. $\mathrm{K}^{+}-\mathrm{Cl}^{-}$- and $\mathrm{Ca}^{2+}$-channels are confined to the rear of the cell, whereas ion pathways leading to local cell swelling (RVI), like e.g. $\mathrm{Na}^{+} / \mathrm{H}^{+}-$ exchangers, $\mathrm{Cl}^{-} / \mathrm{HCO}_{3}$-exchangers and $\mathrm{Na}^{+} / \mathrm{K}^{+} / 2 \mathrm{Cl}^{-}$-cotransporters are sorted to the leading edge. Because blockers of $\mathrm{I}_{\mathrm{Cl} \text {, swell }}$ may block $\mathrm{Cl}^{-}$-channels as well as KCCs, as DIOA does [3, $22,26,37]$, and $\mathrm{Cl}^{-}$-free conditions affects several $\mathrm{Cl}^{-}$-dependent transport proteins like KCCs, NKCCs $[22,38]$, the contribution of these different ion channels and transporters to engulfment pseudopodium formation remains to be characterized. Since all blockers used in the present study suppress at least $\mathrm{Cl}^{-}$-channel activity $[3,22,37,39]$ and lamellipodium formation, we conclude that $\mathrm{Cl}^{-}$-channels contribute significantly in lamellipodium formation. In addition, these ion transport mechanisms are tightly linked to the cytoskeleton and hence regulate the dynamics for adhesion and pseudopodia protrusion [40-42]. Whether a similar polarized distribution of ion channels and transporters is established during the formation of engulfment pseudopodia is, however, not known yet.

Late consequences of $I_{C l \text {, swell }}$ on phagocytosis

Long-term consequences of phagocytosis could include enhancement of volume regulatory mechanisms and/or down-regulation of excess uptake of particles to prevent mechanical rupture of the cell membrane and/or threatening increases in intracellular osmotic pressure following degradation of phagocytosed particles. We assume that phagocytosis promotes long-term activation of $\mathrm{I}_{\mathrm{Cl} \text {, swell }}$ to counterbalance increases in intracellular osmolytes due to degradation and metabolism of phagocytosed material by $\mathrm{CV}$ regulatory ion fluxes. In liver cells, a catabolic signal is associated with water loss and shrinkage and an anabolic signal with water influx and swelling. In hepatocytes, a glucagoncAMP-mediated pathway not only promotes glycogenolysis and gluconeogenesis, but also cell shrinkage, whereas insulin not only facilitates glucose uptake and glycogenesis but also cell swelling [43]. Interestingly, glucagon activates $\mathrm{Cl}^{-}$-channels in hepatocytes via a cAMPEpac-dependent signalling pathway [15]. Similarly to hepatocytes, digestion of engulfed material by phagocytes may increase the intracellular osmotic pressure, which causes an 
influx of water and cell swelling if not counterbalanced by fluxes of osmolytes across the plasma membrane. In the present study we found that uptake of MBs causes an increase in $\mathrm{I}_{\mathrm{Cl}}$, swell density. This may reflect a long-term response of phagocytes to counterbalance an increase in CV or intracellular osmolytes by an increase in ion fluxes across the plasma membrane.

Long-term consequences of osmotic challenges on phagocytosis are documented. Warskulat and co-workers observed that $12 \mathrm{~h}$ exposure of Kupffer cells to hypoosmotic conditions increases phagocytosis of latex MBs, whereas exposure to hyperosmotic conditions decreases phagocytosis [44]. In contrast to our study, these authors exposed Kupffer cells to latex MBs in hypoosmotic and hyperosmotic conditions, respectively, whereas in the present study, BV-2 cells were pre-conditioned in hypoosmotic and hyperosmotic environment, but exposed to MBs in normotonic conditions. Neither condition induced a significant change in $\mathrm{I}_{\mathrm{Cl} \text {, swell }}$ density, indicating that the cells have adequately adapted $\mathrm{I}_{\mathrm{Cl} \text {, swell }}$ to the prevailing anisotonic condition and are able to adjust their set point volume. Nonetheless, the phagocytotic capacity is reduced after both hyper- and hypotonic preconditioning. From the present data we cannot give an explanation for this phenomenon. However, from a hermeneutic point of view it may be assumed, that a cell chronically exposed to anisotonic stress down-regulates processes, which pose further osmotic burden on it, like e.g. phagocytosis.

Most studies on phagocytosis focus on the cytoskeleton. The present study indicates that volume regulation due to $\mathrm{I}_{\mathrm{Cl} \text {, swell }}$ also significantly contributes to the uptake of particles. Since ion channels and transporters are linked to the actin cytoskeleton [45], ion channels in the plasma membrane and the cytoskeleton below the plasma membrane may cooperate to engulf particles.

In conclusion, our observations indicate that phagocytotic uptake of polystyrene microspheres by microglial cells is associated with activation of $\mathrm{Cl}^{-}$-currents, because (i) under $\mathrm{Cl}^{-}$-free extracellular conditions the uptake of microspheres is attenuated, (ii) $\mathrm{Cl}^{-}$channel blockers suppress the extension of engulfment pseudopodia as well as the uptake of microspheres, and (iii) engulfment of microspheres up-regulates $\mathrm{I}_{\mathrm{cl} \text {, swell }}$ (iv). In addition, preconditioning of the cells to hypo- or hyperosmotic conditions decreases microsphere uptake.

\section{Abbreviations}

CLSM (confocal laser scanning microscopy); CV (cell volume); MB (microbead, microsphere); $\mathrm{I}_{\mathrm{Cl}, \text { swell }}$ (swelling-activated Cl-current/conductance); $\mathrm{KCC} \quad\left(\mathrm{K}^{+} / \mathrm{Cl}^{-}\right.$cotransporter); $\mathrm{NKCC}\left(\mathrm{Na}^{+} / \mathrm{K}^{+} / 2 \mathrm{Cl}^{-}\right.$-cotransporter); RVD (regulatory volume decrease); RVI (regulatory volume increase); post-RVD RVI (normotonicity-induced RVI under following hypotonicity-induced RVD); post-RVI RVD (normotonicity-induced RVD following hypertonicity-induced RVI); SEM (scanning electron microscopy).

\section{Acknowledgements}

We dedicate our study to the memory of em. o. Univ.-Prof. Dr. Hans Adam, C. Biol. F. I. Biol. London, who passed away on February $3^{\text {rd }} 2013$.

We thank Karin Oberascher for help in cell culture procedures and technical advice in confocal and electron scanning microscopy and Wolf-Dietrich Krautgartner for providing access to the scanning electron microscope. The technical assistance of Marlena Beyreis and Leman Emin is gratefully acknowledged. This project was supported by the PMU grant R-11/02/024-JAK to MJ. 


\section{Cellular Physiology Cell Physiol Biochem 2013;31:319-337

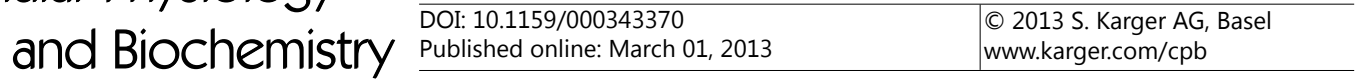 \\ Harl/Schmölzer/Jakab/Ritter/Kerschbaum: Chloride Channel Blockers Suppress Phagocytosis}

\section{References}

1 Busetto S, Trevisan E, Decleva E, Dri P, Menegazzi R: Chloride movements in human neutrophils during phagocytosis: characterization and relationship to granule release. J Immunol 2007;179:4110-4124.

2 Moreland JG, Davis AP, Bailey G, Nauseef WM, Lamb FS: Anion channels, including CIC-3, are required for normal neutrophil oxidative function, phagocytosis, and transendothelial migration. J Biol Chem 2006;281:12277-12288.

3 Ducharme G, Newell EW, Pinto C, Schlichter LC: Small-conductance Cl- channels contribute to volume regulation and phagocytosis in microglia. Eur J Neurosci 2007;26:2119-2130.

$\checkmark 4$ Furtner T, Zierler S, Kerschbaum HH: Blockade of chloride channels suppresses engulfment of microspheres in the microglial cell line, BV-2. Brain Res 2007;1184:1-9.

5 Paradisi S, Matteucci A, Fabrizi C, Denti MA, Abeti R, Breit SN, Malchiodi-Albedi F, Mazzanti M: Blockade of chloride intracellular ion channel 1 stimulates Abeta phagocytosis. J Neurosci Res 2008;15:2488-2498.

6 Painter RG, Valentine VG, Lanson NA Jr, Leidal K, Zhang Q, Lombard G, Thompson C, Viswanathan A, Nauseef WM, Wang G, Wang G: CFTR Expression in human neutrophils and the phagolysosomal chlorination defect in cystic fibrosis. Biochemistry 2006;29:10260-10269.

7 Döring G, Gulbins E: Cystic fibrosis and innate immunity: how chloride channel mutations provoke lung disease. Cell Microbiol 2009;11:208-216.

8 Hoffmann EK, Lambert IH, Pedersen SF: Physiology of cell volume regulation in vertebrates. Physiol Rev 2009;89:193-277.

-9 Lang F: Mechanisms and significance of cell volume regulation. J Am Coll Nutr 2007;26:613S-623S.

10 Okada Y: Ion channels and transporters involved in cell volume regulation and sensor mechanisms. Cell Biochem Biophys 2004;41:233-258.

11 Okada Y, Maeno E, Shimizu T, Dezaki K, Wang J, Morishima S: Receptor-mediated control of regulatory volume decrease (RVD) and apoptotic volume decrease (AVD). J Physiol 2001;1:3-16.

12 Eder C: Ion channels; in Streit W (ed): Microglia in the regenerating and degenerating central nervous system. Springer Verlag New York, Inc, 2002, pp 37-57.

13 Sardini A, Amey JS, Weylandt KH, Nobles M, Valverde MA, Higgins CF: Cell volume relgulation and swellingactivated chloride channels. Biochim Biophys Acta 2003;1618:153-162.

14 Walz W: Chloride/anion channels in glial cell membranes. Glia 2002;40:1-10.

15 Aromataris EC, Roberts ML, Barritt GJ, Rychkov GY: Glucagon activates $\mathrm{Ca}^{2+}$ and $\mathrm{Cl}^{-}$-channels in rat hepatocytes. J Physiol 2006;15:611-625.

16 Dahl S, Hallbrucker C, Lang F, Gerok W, Häussinger D: Regulation of liver cell volume and proteolysis by glucagon and insulin. Biochem J 1991;15:278:771-777.

17 Lang F, Busch GL, Ritter M, Völkl H, Waldegger S, Gulbins E, Häussinger D: Functional significance of cell volume regulatory mechanisms. Physiol Rev 1998;78:247-306.

18 Hoffmann OM, Becker D, Weber JR: Bacterial hydrogen peroxide contributes to cerebral hyperemia during early stages of experimental pneumococcal meningitis. J Cereb Blood Flow Metab 2007;27:1792-1797.

19 Hamill OP, Marty A, Neher E, Sakmann B, Sigworth FJ: Improved patch-clamp techniques for highresolution current recording from cells and cell-free membrane patches. Pflugers Arch 1981;391:85-100.

20 Kerschbaum HH, Negulescu PA, Cahalan MD: Ion channels, $\mathrm{Ca}^{2+}$ signaling, and reporter gene expression in antigen-specific mouse T cells. J Immunol 1997;159:1628-1638.

-21 Svoboda N, Pruetting S, Grissmer S, Kerschbaum HH: cAMP-dependent chloride conductance evokes ammonia-induced blebbing in the microglia cell line, BV-2. Cell Physiol Biochem 2009;24:53-64.

-22 Zierler S, Frei E, Grissmer S, Kerschbaum HH: Chloride influx provokes lamellipodium formation in microglial cells. Cell Physiol Biochem 2008;21:55-62.

-23 Ernest NJ, Weaver AK, Van Duyn LB, Sontheimer HW: Relative contribution of chloride channels and transporters to regulatory volume decrease in human glioma cells. Am J Physiol Cell Physiol 2005;288:C1451-C1460.

24 Gibson JS, Godart H, Ellory JC, Staines H, Honess NA, Cossins AR: Modulation of $\mathrm{K}^{+}-\mathrm{Cl}^{-}$- cotransport in equine red blood cells. Exp Physiol 1995;79:997-1009.

25 Lee YS: Arachidonic acid activates $\mathrm{K}^{+}$- $\mathrm{Cl}^{-}$-cotransport in HepG2 human hepatoblastoma cells. Korean J Physiol Pharmacol 2009;13:401-408. 


\section{Cellular Physiology $\quad$ Cell Physiol Biochem 2013;31:319-337 \begin{tabular}{l|l} 
and BiOchemistry & $\begin{array}{l}\text { DOI: 10.1159/000343370 } \\
\text { Published onIIne: VIarch01, 2013 }\end{array}$ \\
\hline
\end{tabular} \\ Harl/Schmölzer/Jakab/Ritter/Kerschbaum: Chloride Channel Blockers Suppress Phagocytosis}

26 Kurbannazarova RS, Bessonova SV, Okada Y, Sabirov RZ: Swelling-activated anion channels are essential for volume regulation of mouse thymocytes. Int J Mol Sci 2011;12:9125-9137.

27 Nicholl AJ, Killey J, Leonard MN, Garner C: The role of bicarbonate in regulatory volume decrease (RVD) in the epithelial-derived human breast cancer cell line ZR-75-1. Pflugers Arch 2002;443:875-881.

-28 Kouri J, Noa M, Diaz B, Niubo E: Hyperpolarisation of rat peritoneal macrophages phagocytosing latex particles. Nature 1980;283:868-869.

29 Diaz B, Niubo E, Companioni M, Ancheta O, Kouri J: Effects of cytochalasin B and of deoxyglucose on phagocytosis-related changes in membrane potential in rat peritoneal macrophages. Exp Cell Res 1984;150:494-798.

-30 Ince C, Coremans JM, Ypey DL, Leijh PC, Verveen AA, van Furth R: Phagocytosis by human macrophages is accompanied by changes in ionic channel currents. J Cell Biol 1988;106:1873-1878.

-31 Holevinsky KO, Nelson DJ: Simultaneous detection of free radical release and membrane current during phagocytosis. J Biol Chem 1995;270:8328-8336.

-32 Schlichter LC, Mertens T, Liu B: Swelling activated $\mathrm{Cl}^{-}$channels in microglia: Biophysics, pharmacology and role in glutamate release. Channels 2011;5:128-137.

-33 Botchkin LM, Matthews G: Swelling activates chloride current and increases internal calcium in nonpigmented epithelial cells from the rabbit ciliary body. J Cell Physiol 1995;164:286-294.

-34 Rothstein A, Mack E: Volume-activated $\mathrm{K}^{+}$and $\mathrm{Cl}^{-}$pathways of dissociated epithelial cells (MDCK): role of $\mathrm{Ca}^{2+}$. Am J Physiol 1990;258:C827-C834.

-35 Carpenter E, Peers C: Swelling- and cAMP-activated $\mathrm{Cl}^{-}$currents in isolated rat carotid body type I cells. J Physiol 1997;15:497-511.

-36 Meng XJ, Weinman SA: cAMP- and swelling-activated chloride conductance in rat hepatocytes. Am J Physiol 1996;271:C112-C120.

-37 Fürst J, Gschwentner M, Ritter M, Bottà G, Jakab M, Mayer M, Garavaglia L, Bazzini L, Rodighiero S, Meyer G, Eichmüller S, Wöll E, Paulmichl M: Molecular and functional aspects of anionic channels activated during regulatory volume decrease in mammalian cells. Pflugers Arch - Eur J Physiol 2002;444:1-25.

-38 Flatman PW: Regulation of Na-K-2Cl cotransport by phosphorylation and protein-protein interactions. Biochim Biophys Acta 2002;1566:140-151.

-39 Decher N, Lang HJ, Nilius B, Brüggemann A, Busch AE, Steinmeyer K: DCPIB is a novel selective blocker of $\mathrm{I}_{\mathrm{Cl}, \text { swell }}$ and prevents swelling-induced shortening of guinea-pig atrial action potential duration. Br J Pharmacol 2001;134:1467-79.

40 Jakab M, Ritter M: Cell volume regulatory ion transport in the regulation of cell migration. Contrib Nephrol 2006;152:161-180.

41 Schwab A: Function and spatial distribution of ion channels and transporters in cell migration. Am J Physiol Renal Physiol 2001;280:F739-F747.

42 Schwab A, Nechyporuk-Zloy V, Fabian A, Stock C: Cells move when ions and water flow. Pflugers Arch - Eur J Physiol 2007;453:421-432.

43 Häussinger D: The role of cellular hydration in the regulation of cell function. Biochem J 1996;313:697710.

-44 Warskulat U, Zhang F, Häussinger D: Modulation of phagocytosis by anisoosmolarity and betaine in rat liver macrophages (Kupffer cells) and RAW 264.7 mouse macrophages. FEBS Lett 1996;391:287-292.

45 Henson JH: Relationships between the actin cytoskeleton and cell volume regulation. Microsc Res Tech 1999;47:155-162. 